\title{
A Systematic Study Reveals that Xylella fastidiosa Strains from Pecan Are Part of $X$. fastidiosa subsp. multiplex
}

R. A. Melanson, Department of Plant Pathology and Crop Physiology, Louisiana State University Agricultural Center, Baton Rouge, LA 70803, USA; R. S. Sanderlin, Louisiana State University Agricultural Center Pecan Research-Extension Station, Shreveport, LA 71115, USA; and A. R. McTaggart and J. H. Ham, Department of Plant Pathology and Crop Physiology, Louisiana State University Agricultural Center, Baton Rouge, LA 70803, USA

\begin{abstract}
Melanson, R. A., Sanderlin, R. S., McTaggart, A. R., and Ham, J. H. 2012. A systematic study reveals that Xylella fastidiosa strains from pecan are part of X. fastidiosa subsp. multiplex. Plant Dis. 96:1123-1134.

Xylella fastidiosa causes disease in a number of economically important crops, ornamental plants, and shade trees, including grapevine, citrus, oleander, and sycamore. In pecan, X. fastidiosa causes pecan bacterial leaf scorch (PBLS), which leads to defoliation and reduces nut yield. No economically effective treatments are available for PBLS. In order to improve PBLS management practices, it is necessary to determine the subspecies of $X$. fastidiosa strains that infect pecan so that potential sources of inoculum may be identified. Multiprimer polymerase chain reaction (PCR) and phylogenetic analyses using nucleotide sequence data from the 16S-23S rRNA intergenic tran-

scribed spacer (ITS) region and pglA consistently identified strains of $X$. fastidiosa isolated from pecan as $X$. fastidiosa subsp. multiplex. Enterobacterial repetitive intergenic consensus PCR and repetitive extragenic palindromic (REP)-PCR analyses were congruent with phylogenetic analyses. REP-PCR analyses indicated genetic variation within strains of $X$. fastidiosa from pecan. From these same analyses, $X$. fastidiosa strains from sycamore, grapevine, and oleander from Louisiana were identified as subsp. multiplex, subsp. fastidiosa, and subsp. sandyi, respectively. This study provides additional information about the host ranges of $X$. fastidiosa subspecies.
\end{abstract}

Xylella fastidiosa is a gram-negative, xylem-limited, fastidious bacterium that causes disease in a number of economically important crops, ornamental plants, and shade trees, including grapevine, peach, citrus, oleander, and sycamore $(6,14,39,58,67)$. Symptoms of disease in these hosts typically include scorching of leaves, reduced growth, defoliation, plant death, or chlorosis $(8,23,39$, $46,58,59)$. Insect transmission by xylem-feeding insects in the families Cercopidae and Cicadellidae is considered the primary means of transmission of $X$. fastidiosa from infected to noninfected plant hosts (41); however, other forms of transmission, including graft transmission and seed transmission, have also been reported in some hosts $(7,30,41,45)$.

Five subspecies of $X$. fastidiosa have been determined since the genus and species was first described by Wells et al. in 1987 $(40,54,55,57,67)$. These include $X$. fastidiosa subsp. fastidiosa, which infects and causes disease in grapevine and almond, as well as in other plant hosts $(54,55) ; X$. fastidiosa subsp. pauca, which infects citrus and coffee and is the only described subspecies not present in North America (35,54); X. fastidiosa subsp. multiplex, which infects a large number of plant hosts, including almond, elm, peach, pigeon grape, plum, sycamore, and other shade trees (54); X. fastidiosa subsp. sandyi, which infects oleander and some other hosts $(21,57)$; and the most recently described subspecies, $X$. fastidiosa subsp. tashke, which infects chitalpa in the southwestern United States (40). These subspecies are based on various phenotypic and genotypic factors such as DNA-DNA relatedness, DNA sequence variation, growth characteristics in vitro, and the ability of strains to grow in or infect particular hosts $(40,54,57)$. Some degree of host specificity exists among subspecies and strains of $X$. fastidiosa; however, this specificity is not always clear and some subspecies and strains are able to infect multiple plant hosts (22).

Corresponding author: J. H. Ham, E-mail: JHam@agcenter.lsu.edu

Accepted for publication 20 February 2012.

http://dx.doi.org/10.1094/PDIS-09-11-0730-RE

(C) 2012 The American Phytopathological Society
In Louisiana, $X$. fastidiosa strains have been isolated from various plants, including a grapevine with Pierce's disease (PD) and a sycamore tree and an oleander plant with leaf scorch (60).

$X$. fastidiosa $9 \mathrm{a} 5 \mathrm{c}$, a strain isolated from citrus (sweet orange), was the first plant-pathogenic bacterium to have its genome completely sequenced (59). Since then, additional strains of $X$. fastidi$o s a$, including strains from almond and grapevine, have been completely sequenced; sequence information for these whole genomes as well as many DNA regions and genes of other strains is available in the National Center for Biotechnology Information (NCBI) GenBank database $(9,56,65)$. The availability of these complete genome sequences, as well as other sequence information from the $16 \mathrm{~S}$ rRNA, the 16S-23S rRNA internal transcribed spacer (ITS) region, and various housekeeping and pathogenicity-related genes, has enabled comparative genomic or genetic analyses among strains from different hosts and subspecies and has led to assays for the differentiation of subspecies as well as the identification of new subspecies $(19,20,24,57,63,65)$.

In 2000, X. fastidiosa was reported as the causative agent of pecan bacterial leaf scorch (PBLS; 46). The symptoms of PBLS are similar to those caused by the bacterium in other plant hosts and include leaflets turning tan to brown beginning at the margin and progressing basipetally, followed by abscission of infected leaflets (46). This disease tends to occur annually and has been identified in over 20 pecan cultivars and in nongrafted trees $(45,50)$. X. fastidiosa threatens the pecan industry by causing reduced nut yields in infected trees. In pecan 'Cape Fear' trees, diseased terminals had reduced kernel weights that averaged $16 \%$ less when compared with noninfected terminals in the same orchard (47). Currently, only management strategies to reduce the introduction of this pathogen into pecan orchards exist. No resistant pecan cultivar has been identified, and there is no treatment for trees that become infected.

Compared with other diseases caused by $X$. fastidiosa, PBLS is a recently recognized disease. The majority of the studies on PBLS have been focused on the transmission of the pathogen in pecan $(45-49,51,52)$. Because pecan cultivars are clonally propagated, graft transmission of the pathogen may be a major source of pathogen spread into orchards. X. fastidiosa can be transmitted from 
either scions or rootstocks obtained from infected pecan trees following grafting $(45,49)$. A hot-water treatment of pecan scion wood reduced graft transmission of the pathogen; however, the pathogen continues to spread in established orchards, apparently by insect transmission $(29,48,51)$. Most recently, insect transmission tests in pecan have shown that the pecan spittlebug, Clastoptera achatina, and several leafhopper species, including the glassy-winged sharpshooter (GWSS), Homalodisca vitripennis, and the Johnsongrass sharpshooter, $H$. insolita, are able to transmit $X$. fastidiosa from infected to noninfected pecan with subsequent PBLS development (52).

Prior to this work, pecan strains of $X$. fastidiosa had not been studied well. However, a paper that came out while this manuscript was in review reported that strains of $X$. fastidiosa from pecan might be grouped within $X$. fastidiosa subsp. multiplex (63). The taxonomical identification of the pecan strains, as well as their relationship to other strains of $X$. fastidiosa present in Louisiana and in other hosts, would aid in the development of more effective management strategies for PBLS. These strategies should take into account other plant hosts in and around pecan orchards that may harbor the same subspecies and serve as sources of inoculum for transmission by insect vectors, such as the GWSS, that feed on and transmit the pathogen in several hosts $(1,4,12,28,39)$.

This study determined the subspecies of $X$. fastidiosa strains isolated from pecan and other hosts in Louisiana and the phylogenetic relationship among the strains using a multiprimer polymerase chain reaction (PCR) assay, DNA sequence analyses, and rep-PCR techniques. The information obtained through this study will contribute to a better understanding of PBLS epidemiology and $X$. fastidiosa population biology by helping to identify potential sources of $X$. fastidiosa inoculum for pecan and by providing new strain information that can be used to study and understand the diversity found within this species.

\section{Materials and Methods}

Bacterial strains, isolation, growth conditions, and DNA extraction. $X$. fastidiosa strains used in this study are listed in Table 1. Bacterial strains were previously isolated from plant tissue showing scorch-like symptoms by squeezing plant sap from pecan rachises and from grapevine and sycamore petioles directly onto modified periwinkle wilt medium (13) and subsequently incubating the culture plates in the dark at $28^{\circ} \mathrm{C}$. Culture plates were examined periodically and individual colonies resembling $X$. fastidiosa were transferred to tubes containing $30 \%$ glycerol and stored at -60 to $-70^{\circ} \mathrm{C}$. The strain from oleander was isolated as previously described (60).

Strains from pecan, grapevine, and sycamore previously tested positive for $X$. fastidiosa with a commercial $X$. fastidiosa doubleantibody sandwich enzyme-linked immunosorbent assay (ELISA) kit (Agdia, Inc., Elkhart, IN). The oleander strain, XF Oleander, was previously verified as $X$. fastidiosa using a $X$. fastidiosaspecific primer set $(24,60)$. All strains were recovered from glyc- erol storage and grown on modified periwinkle wilt medium at $28^{\circ} \mathrm{C}$. Genomic DNA was extracted from 11-day-old cultures of all pecan, grapevine, and oleander strains and from a 1-month-old culture of the sycamore strain using the GenElute Bacterial Genomic DNA Extraction kit (Sigma-Aldrich, St. Louis, MO). DNA samples were stored at $-20^{\circ} \mathrm{C}$ for long-term use or $4^{\circ} \mathrm{C}$ for shortterm use.

PCR and electrophoresis conditions. All PCRs were performed in a DNA Engine Peltier Thermal Cycler (Bio-Rad, Hercules, CA). PCR reagents and DNA template solutions were used at the following concentrations: GeneAmp 10× PCR Buffer I containing $15 \mathrm{mM} \mathrm{MgCl}$ (Applied Biosystems, Carlsbad, CA); 10× EasyA reaction buffer (Agilent Technologies, Santa Clara, CA); EasyA high-fidelity PCR cloning enzyme, $5 \mathrm{U} / \mu \mathrm{l}$ (Agilent Technologies); homemade Taq polymerase, approximately $1.0 \mathrm{U} / \mu \mathrm{l}$; primers, $10 \mu \mathrm{M} ; \mathrm{MgCl}_{2}, 50 \mathrm{mM}$; dNTP mix, $10 \mathrm{mM}$; and DNA template, $1 \mathrm{ng} / \mu \mathrm{l}$. Sterile distilled deionized water was used to bring the volume up to the desired reaction volume. Primers used in this study were synthesized by Bioneer, Inc. (Alameda, CA). Primer sequences are listed in Table 2.

Agarose gels contained ethidium bromide for visualization of PCR products under UV light. Unless specified, gels were run under standard conditions in 1× Tris-borate EDTA buffer (44). PCR products were visualized and photographed with a KODAK Gel Logic 1500 Imaging System (Eastman Kodak Company, Rochester, NY).

$X$. fastidiosa-specific PCR. Standard PCR was performed on all strains of $X$. fastidiosa from Louisiana with primers RST31 and RST33 (Table 2) to confirm previous ELISA and PCR results. Each reaction contained $2 \mu \mathrm{l}$ of template DNA, $2.5 \mu \mathrm{l}$ of GeneAmp 10× PCR Buffer I, $1.0 \mu \mathrm{l}$ of each primer, $0.5 \mu \mathrm{l}$ of dNTP mix, and 1 $\mu \mathrm{l}$ of Taq polymerase in a total reaction volume of $25 \mu \mathrm{l}$. The PCR program included an initial denaturation period of $95^{\circ} \mathrm{C}$ for $1 \mathrm{~min}$; 40 cycles of $95^{\circ} \mathrm{C}$ for $30 \mathrm{~s}, 55^{\circ} \mathrm{C}$ for $30 \mathrm{~s}$, and $72^{\circ} \mathrm{C}$ for $45 \mathrm{~s}$; and a final extension period of $72^{\circ} \mathrm{C}$ for $5 \mathrm{~min}$ (34). PCR products were separated by gel electrophoresis in a 0.7 or $1 \%$ agarose gel. PCR was repeated at least twice for each bacterial strain.

Multiprimer PCR assay. A multiprimer PCR assay designed by Hernandez-Martinez et al. (18) was performed on all strains of $X$. fastidiosa from Louisiana. Each reaction contained $2 \mu$ of template DNA; $2.5 \mu$ l of GeneAmp 10× PCR Buffer I; $1.0 \mu$ l each of primers XF1968-L, XF1968-R, XF2542-L, XF2542-R, ALM1, and ALM2 (Table 2); $0.5 \mu \mathrm{l}$ of dNTP mix; and $1.0 \mu \mathrm{l}$ of Taq polymerase in a total reaction volume of $25 \mu \mathrm{l}$. The PCR program included an initial denaturation period of $94^{\circ} \mathrm{C}$ for $5 \mathrm{~min} ; 40$ cycles of $94^{\circ} \mathrm{C}$ for 1 $\min , 55^{\circ} \mathrm{C}$ for $1 \mathrm{~min}$, and $72^{\circ} \mathrm{C}$ for $1 \mathrm{~min}$; and a final extension period of $72^{\circ} \mathrm{C}$ for $10 \mathrm{~min}$ (20). Multiprimer PCR products were separated by gel electrophoresis in a $1.5 \%$ agarose gel. PCR products were visualized and photographed as previously described. PCR was repeated at least twice for each bacterial strain.

PCR and sequence analysis of the 16S-23S rRNA ITS and pglA. Primers G1 and L1 (Table 2) were used to amplify the 16S-

Table 1. Strains of Xylella fastidiosa isolated from symptomatic plant tissue and used in this study

\begin{tabular}{|c|c|c|c|}
\hline Strain designation & Host plant (cultivar) ${ }^{\mathrm{a}}$ & Location of plant host ${ }^{b}$ & Year of isolation \\
\hline XF A-05 & Carya illinoinensis pecan (Cape Fear) & Shreveport, $\mathrm{LA}^{\mathrm{c}}$ & 2005 \\
\hline XF B-05 & C. illinoinensis pecan (Cape Fear) & Shreveport, $\mathrm{LA}^{\mathrm{c}}$ & 2005 \\
\hline XF C-05 & C. illinoinensis pecan (Cape Fear) & Shreveport, $\mathrm{LA}^{\mathrm{c}}$ & 2005 \\
\hline XF A-06 & C. illinoinensis pecan (Cape Fear) & Shreveport, $\mathrm{LA}^{\mathrm{c}}$ & 2006 \\
\hline XF A-07 & Platanus occidentalis sycamore & Shreveport, LA & 2007 \\
\hline XF D-07 & C. illinoinensis pecan (Cape Fear) & Shreveport, $\mathrm{LA}^{\mathrm{c}}$ & 2007 \\
\hline XF A-08 & Vitis vinifera grapevine & Hessmer, $\mathrm{LA}^{\mathrm{d}}$ & 2008 \\
\hline XF Oleander & Nerium oleander oleander & Baton Rouge, LA & 2009 \\
\hline XF A-10 & C. illinoinensis pecan (Oconee) & Hessmer, LA ${ }^{\mathrm{d}}$ & 2010 \\
\hline XF B-10 & C. illinoinensis pecan (Desirable) & Hessmer, LA ${ }^{\mathrm{d}}$ & 2010 \\
\hline
\end{tabular}

\footnotetext{
a Scientific name, common name, and cultivar (in parentheses) for host plant are given whenever the information is known.

b Shreveport, LA, is located in Caddo Parish; Hessmer, LA, is located in Avoyelles Parish; Baton Rouge, LA, is located in East Baton Rouge Parish.

c Strains were isolated from symptomatic orchard trees or trees in pots at the Pecan Research-Extension Station in Shreveport, LA.

d Strains were isolated from symptomatic trees or vines growing at the same location in Hessmer, LA.
} 
23S rRNA ITS region of all strains of $X$. fastidiosa. Each reaction contained $15 \mu \mathrm{l}$ of template DNA, $5.0 \mu \mathrm{l}$ of GeneAmp 10× PCR Buffer I, $2 \mu \mathrm{l}$ of each primer, $1.0 \mu \mathrm{l}$ of dNTP mix, and $1.5 \mu \mathrm{l}$ of Taq polymerase in a total reaction volume of $50 \mu \mathrm{l}$. The PCR program, modified from Hendson et al. (19), included an initial denaturation period of $94^{\circ} \mathrm{C}$ for $5 \mathrm{~min} ; 21$ cycles of $94^{\circ} \mathrm{C}$ for $40 \mathrm{~s}, 55^{\circ} \mathrm{C}$ for 1 min, and $72^{\circ} \mathrm{C}$ for $2 \mathrm{~min}$; and a final extension period of $72^{\circ} \mathrm{C}$ for $10 \mathrm{~min}$.

Primers XFPglA_Fw and XFPglA_Rv (Table 2) were designed within homologous regions surrounding the designated pglA gene in the complete genome sequences of $X$. fastidiosa strains $9 \mathrm{a} 5 \mathrm{c}$, Temecula1, M12, and M23 available in NCBI's GenBank to amplify the pglA gene of strains of X. fastidiosa. Each reaction contained $1.0 \mu \mathrm{l}$ of template DNA, $5.0 \mu \mathrm{l}$ of $10 \times$ EasyA reaction buffer, $2 \mu \mathrm{l}$ of each primer, $1.5 \mu \mathrm{l}$ of $\mathrm{MgCl}_{2}, 1.0 \mu \mathrm{l}$ of dNTP mix, and $0.2 \mu \mathrm{l}$ of EasyA enzyme for a total reaction volume of $50 \mu$ l. The PCR program included an initial denaturation period of $95^{\circ} \mathrm{C}$ for $5 \mathrm{~min}$; 21 cycles of $94^{\circ} \mathrm{C}$ for $40 \mathrm{~s}, 60^{\circ} \mathrm{C}$ for $30 \mathrm{~s}$, and $72^{\circ} \mathrm{C}$ for $2 \mathrm{~min}$; and a final extension period of $72^{\circ} \mathrm{C}$ for $7 \mathrm{~min}$.

Aliquots of the ITS and $p g l A$ PCR products were separated by gel electrophoresis in a 0.7 or $1.0 \%$ agarose gel to confirm PCR product. The remaining ITS and $p g l A$ PCR products were purified using the QuickClean 5M PCR Purification Kit (GenScript, Piscataway, NJ). Purified PCR products were sequenced by the Louisiana State University School of Veterinary Medicine's GeneLab (Baton Rouge) or by Macrogen Inc. (Seoul, Korea). Products from at least two independent PCR reactions were sequenced for each DNA sample to ensure correct base identification, with the exception of strain XF B-10 from pecan, whose sequence was determined from a single product.

ITS and pglA sequences were analyzed with Geneious Pro 5.4 (Biomatters Ltd., Auckland, New Zealand) (16). Alignment of sequences was performed with ClustalW2 (European Molecular Biology Laboratory's European Bioinformatics Institute, www.ebi. ac.uk) (10). pglA sequences were translated into protein sequences using ExPASy Translate (Swiss Institute of Bioinformatics, http://expasy.org/) (17).

Rep-PCR fingerprinting. Rep-PCRs were performed on the basis of two repetitive elements: enterobacterial repetitive intergenic consensus (ERIC)-PCR and repetitive extragenic palindromic (REP)-PCR (66). Each reaction contained: for ERIC-PCR, $2 \mu \mathrm{l}$ of template DNA, $2.5 \mu \mathrm{l}$ of GeneAmp 10× PCR Buffer I, 5.0 $\mu \mathrm{l}$ each of primers ERIC1R and ERIC2 (Table 2), $0.8 \mu \mathrm{l}$ of dNTP mix, and $1.0 \mu \mathrm{l}$ of $\mathrm{Taq}$ polymerase in a total reaction volume of 25 $\mu \mathrm{l}$; and, for REP-PCR, $2 \mu \mathrm{l}$ of template DNA, $2.5 \mu \mathrm{l}$ of GeneAmp $10 \times$ PCR Buffer I, $5.0 \mu \mathrm{l}$ each of primers REP1R-I and REP2-I (Table 2), $0.8 \mu \mathrm{l}$ of dNTP mix, and $1.0 \mu \mathrm{l}$ of Taq polymerase in a total reaction volume of $25 \mu$. PCR programs were performed as previously described and included: for ERIC-PCR, an initial denaturation period of $95^{\circ} \mathrm{C}$ for $7 \mathrm{~min}$; 30 cycles of $94^{\circ} \mathrm{C}$ for 1 min, $52^{\circ} \mathrm{C}$ for $1 \mathrm{~min}$, and $65^{\circ} \mathrm{C}$ for $8 \mathrm{~min}$; and a final extension period of $65^{\circ} \mathrm{C}$ for $16 \mathrm{~min}$; and, for REP-PCR, an initial denaturation period of $95^{\circ} \mathrm{C}$ for $6 \mathrm{~min} ; 30$ cycles of $94^{\circ} \mathrm{C}$ for 1 min, $40^{\circ} \mathrm{C}$ for $1 \mathrm{~min}$, and $65^{\circ} \mathrm{C}$ for $4 \mathrm{~min}$; and a final extension period of $65^{\circ} \mathrm{C}$ for $16 \mathrm{~min}$ (32).

ERIC-PCR and REP-PCR products $(10 \mu \mathrm{l})$ were separated by gel electrophoresis in a $1.8 \%$ agarose gel at $60 \mathrm{~V}$ for $14 \mathrm{~h}$ at 4 to $6^{\circ} \mathrm{C}$. Each rep-PCR was repeated at least three times. The presence or absence of bands between 100 and $1,650 \mathrm{bp}$ for ERIC-PCR and between 400 and 2,000 bp for REP-PCR was recorded. A consensus dataset for distinguishable bands that regularly appeared within these ranges in rep-PCR fingerprints was used for phylogenetic reconstruction.

Phylogenetic analyses. DNA sequences of $X$. fastidiosa strains used for comparative analyses in this study were obtained from NCBI's GenBank (Table 3).

ITS sequences from 49 strains of $X$. fastidiosa and one strain of Xanthomonas campestris pv. campestris were aligned with MUSCLE and cured in Gblocks (Méthodes et Algorithmes pour la Bio-informatique LIRMM, http://www.phylogeny.fr/version2_cgi/ index.cgi) (15). A maximum likelihood (ML) search for the bestscoring ML tree of the cured ITS sequences was performed in RAxML using the rapid bootstrapping algorithm and the GTRMIX model of evolution $(61,62)$. Analyses were run with 1,000 bootstrap replicates. A Markov Chain Monte Carlo (MCMC) search for the cured ITS sequences was performed in MrBayes 3.1 $(25,27,42)$. Four runs each with four chains were tested until the standard deviation of the split frequencies reached 0.01. A starting tree obtained from the ML analysis was used for Bayesian analysis.

The aligned pglA and pglA-homologous sequences from 13 strains of X. fastidiosa were analyzed in RAxML and MrBayes 3.1, as previously described, except that MCMC search runs were tested until the standard deviation of the split frequencies reached 0.02 , and no starting tree was used.

Phylogenetic reconstruction using the unweighted pair-group method with arithmetic means (UPGMA) was performed in MEGA5 for the individual and combined datasets of binary data for ERIC-PCR and REP-PCR (64). Analyses were run with 1,000 bootstrap replicates. An MCMC search for the individual and combined datasets for ERIC-PCR and REP-PCR was performed in MrBayes 3.1. Four runs each with four chains were tested until the standard deviation of the split frequencies reached 0.01 .

An MCMC search for the total combined dataset of 49 strains of $X$. fastidiosa and one strain of $X$. campestris pv. campestris, including the aligned and cured ITS sequences, the aligned pglA sequences, and the binary data from ERIC-PCR and REP-PCR, was performed in MrBayes 3.1. Four runs each with four chains were tested until the standard deviation of the split frequencies

Table 2. Primers used in this study

\begin{tabular}{|c|c|c|c|}
\hline Primer name & Primer sequence $\left(5^{\prime} \rightarrow 3^{\prime}\right)$ & Test $^{\mathbf{a}}$ & Reference \\
\hline RST31 & GCGTTAATTTTCGAAGTGATTCGATTGC & Species ID & 34 \\
\hline RST33 & CACCATTCGTATCCCGGTG & Species ID & 34 \\
\hline XF1968-L & GGAGGTTTACCGAAGACAGAT & Multiprimer PCR & 20 \\
\hline XF1968-R & ATCCACAGTAAAACCACATGC & Multiprimer PCR & 20 \\
\hline XF2542-L & TTGATCGAGCTGATGATCG & Multiprimer PCR & 20 \\
\hline XF2542-R & CAGTACAGCCTGCTGGAGTTA & Multiprimer PCR & 20 \\
\hline ALM1 & CTGCAGAAATTGGAAACTTCAG & Multiprimer PCR & 20 \\
\hline ALM2 & GCCACACGTGATCTATGAA & Multiprimer PCR & 20 \\
\hline G1 & GAAGTCGTAACAAGG & ITS amplification & 26 \\
\hline L1 & CAAGGCATCCACCGT & ITS amplification & 26 \\
\hline XFPglA_Fw & GCCTCCGGTGCGACTGCTTC & pglA amplification & This study \\
\hline XFPglA_Rv & GCTGCGATTGGACACACATTG & pglA amplification & This study \\
\hline ERIC1R & ATGTAAGCTCCTGGGGATTCAC & ERIC-PCR & 66 \\
\hline ERIC2 & AAGTAAGTGATGGGGTGAGCG & ERIC-PCR & 66 \\
\hline REP1R-I & IIIICGICGICATCIGGC & REP-PCR & 66 \\
\hline REP2-I & ICGICTTATCIGGCCTAC & REP-PCR & 66 \\
\hline
\end{tabular}

${ }^{\text {a }}$ PCR $=$ polymerase chain reaction, ITS $=$ intergenic transcribed spacer, ERIC $=$ enterobacterial repetitive intergenic consensus, and REP $=$ repetitive extragenic palindromic. 
Table 3. Bacterial strains and sequences used in this study for phylogenetic analysis

\begin{tabular}{|c|c|c|c|c|c|}
\hline Strain designation & Plant host & $\begin{array}{c}\text { Geographical } \\
\text { origin }\end{array}$ & $\begin{array}{c}\text { GenBank } \\
\text { accession number }\end{array}$ & $\begin{array}{c}\text { Accession number } \\
\text { description }^{\mathrm{a}}\end{array}$ & Reference \\
\hline \multicolumn{6}{|l|}{ Xylella fastidiosa } \\
\hline M12 & Almond & California & СР000941 & Complete genome & 9 \\
\hline M23 & Almond & California & СР001011 & Complete genome & 9 \\
\hline ALS1 & Almond & California & AF073240 & Partial ITS & 19 \\
\hline Tulare & Almond & California & AF073242 & Partial ITS & 19 \\
\hline Contra Costa & Almond & California & AF073250 & Partial ITS & 19 \\
\hline Dixon & Almond & California & AF073251 & Partial ITS & 19 \\
\hline Fresno & Almond & California & DQ011259 & Partial ITS & 20 \\
\hline AZ03 & Chitalpa & Arizona & EU714189 & Partial ITS & 40 \\
\hline CA01 & Chitalpa & California & EU714190 & Partial ITS & 40 \\
\hline NM02 & Chitalpa & New Mexico & EU714192 & Partial ITS & 40 \\
\hline $9 \mathrm{a} 5 \mathrm{c}$ & Citrus & Brazil & AE003849 & Complete genome & 59 \\
\hline CI.52 & Citrus & Brazil & AF203393 & Partial ITS & 33 \\
\hline CI.11067 & Citrus & Brazil & AF237650 & Partial ITS & 33 \\
\hline CI.X0 & Citrus & Brazil & AF237651 & Partial ITS & 33 \\
\hline CO.01 & Coffee & Brazil & AF203394 & Partial ITS & 33 \\
\hline P3 & Coffee & Brazil & AY388464 & Partial ITS & 31 \\
\hline ELM-1 & Elm & Washington & AY388468 & Partial ITS & 31 \\
\hline Temecula 1 & Grapevine & California & AE009442 & Complete genome & 65 \\
\hline GB514 & Grapevine & Texas & СР002165 & Complete genome & 56 \\
\hline PD 95-2 & Grapevine & Florida & AF073220 & Partial ITS & 19 \\
\hline PD 95-4 & Grapevine & Florida & AF073221 & Partial ITS & 19 \\
\hline P 95-9 & Grapevine & Florida & AF073222 & Partial ITS & 19 \\
\hline R116V3 & Grapevine & Florida & AF073223 & Partial ITS & 19 \\
\hline R116V3-4 & Grapevine & Florida & AF073224 & Partial ITS & 19 \\
\hline Conn Creek & Grapevine & California & AF073225 & Partial ITS & 19 \\
\hline Santa Cruz & Grapevine & California & AF073229 & Partial ITS & 19 \\
\hline Preston Ranch & Grapevine & California & AF073232 & Partial ITS & 19 \\
\hline Moore Park & Grapevine & California & AF073236 & Partial ITS & 19 \\
\hline \multirow[t]{2}{*}{ XF A-08 } & Grapevine & Louisiana & JN092384 & Partial ITS & This study \\
\hline & & & JN092393 & pglA & This study \\
\hline Acer macrophyla & Maple & California & AF073219 & Partial ITS & 19 \\
\hline MUL-1 & Mulberry & Massachusetts & AY388467 & Partial ITS & 31 \\
\hline $88-9$ & Oak & Florida & AF073210 & Partial ITS & 19 \\
\hline $92-3$ & Oak & Florida & AF073211 & Partial ITS & 19 \\
\hline $92-10$ & Oak & Florida & AF073212 & Partial ITS & 19 \\
\hline OLS\#2 & Oak & Georgia & AF073213 & Partial ITS & 19 \\
\hline Stucky & Oak & Georgia & AF073214 & Partial ITS & 19 \\
\hline Ann1 & Oleander & California & AF073215 & Partial ITS & 19 \\
\hline PF1 & Oleander & California & AF073216 & Partial ITS & 19 \\
\hline H44 & Oleander & California & AY603088 & Partial ITS & 11 \\
\hline Riverside & Oleander & California & DQ011263 & Partial ITS & 20 \\
\hline Texas & Oleander & Texas & DQ011264 & Partial ITS & 20 \\
\hline \multirow{2}{*}{ XF Oleander } & Oleander & Louisiana & JN092385 & Partial ITS & This study \\
\hline & & $\ldots$ & JN092394 & pglA & This study \\
\hline $5 \mathrm{~S} 2$ & Peach & Georgia & AF073206 & Partial ITS & 19 \\
\hline $5 \mathrm{R} 1$ & Peach & Georgia & AF073207 & Partial ITS & 19 \\
\hline $4 \mathrm{~S} 3$ & Peach & Georgia & AF073208 & Partial ITS & 19 \\
\hline PE.PLS & Pear & Taiwan & AF203396 & Partial ITS & 33 \\
\hline \multirow[t]{2}{*}{ XF A-05 } & Pecan & Louisiana & JN092378 & Partial ITS & This study \\
\hline & & & JN092387 & pglA & This study \\
\hline \multirow{2}{*}{ XF B-05 } & Pecan & Louisiana & JN092379 & Partial ITS & This study \\
\hline & & & JN092388 & pglA & This study \\
\hline \multirow[t]{2}{*}{ XF C-05 } & Pecan & Louisiana & JN092380 & Partial ITS & This study \\
\hline & & & JN092389 & pglA & This study \\
\hline \multirow[t]{2}{*}{ XF A-06 } & Pecan & Louisiana & JN092381 & Partial ITS & This study \\
\hline & & & JN092390 & $p g l A$ & This study \\
\hline \multirow[t]{2}{*}{ XF D-07 } & Pecan & Louisiana & JN092383 & Partial ITS & This study \\
\hline & & & JN092392 & pglA & This study \\
\hline XF B-10 & Pecan & Louisiana & JN092386 & Partial ITS & This study \\
\hline PWT-22 & Periwinkle & Florida & AY388470 & Partial ITS & 31 \\
\hline $2 \# 4$ & Plum & Georgia & AF073209 & Partial ITS & 19 \\
\hline PL.788 & Plum & Georgia & AF203395 & Partial ITS & 33 \\
\hline RGW-R & Ragweed & Florida & AY388469 & Partial & 31 \\
\hline \multirow[t]{2}{*}{ XF A-07 } & Sycamore & Louisiana & JN092382 & Partial ITS & This study \\
\hline & & $\ldots$ & JN092391 & $p g l A$ & This study \\
\hline \multicolumn{6}{|c|}{ Xanthomonas campestris pv. campestris } \\
\hline LMG 568 & $\ldots$ & $\ldots$ & AF209755 & Complete ITS & 18 \\
\hline
\end{tabular}

a Subspecies designations for the complete genomes of strains are as follows: M12, an almond leaf scorch (ALS) strain, is a Xylella fastidiosa subsp. multiplex strain; M23, an ALS strain, and Temecula1 and GB514, Pierce's disease strains, are X. fastidiosa subsp. fastidiosa strains; and 9a5c, a citrus variegated chlorosis strain, is a $X$. fastidiosa subsp. pauca strain. ITS = intergenic transcribed spacer region between the $16 \mathrm{~S}$ and $23 \mathrm{~S}$ ribosomal subunits described in the National Center for Biotechnology Information (NCBI) GenBank as the 16S-23S ribosomal RNA intergenic spacer. pglA was designated as the sequence description for the strains used in this study based on the homology with the polygalacturonase gene in the complete genome sequences of X. fastidiosa strains 9 a5c, Temecula1, M12, M23, and GB514 available in NCBI's GenBank. 
reached 0.02. A starting tree obtained from the ML analysis for the aligned and cured ITS sequences was used for the MCMC search. Because pglA sequences were only available for strains whose complete genomes have been published, these sequences were included with the ITS sequences in the combined dataset so that a pglA sequence from a particular subspecies and host was included with the ITS sequence of a strain from the same subspecies and host. These sequences were included as follows: 9a5c pglA sequence included with strain CI.X0, Temecula1 pglA sequence included with strain PD 95-2, GB514 pglA sequence included with strain PD 95-4, M12 pglA sequence included with strain Dixon, and M23 pglA sequence included with strain ALS1.

Convergence of all Bayesian analyses was tested using the cumulative and compare functions in AWTY (http://king2.scs.fsu. edu/CEBProjects/awty/awty_start.php) (36). Phylogenetic trees were obtained from RAxML for ITS sequence, pglA sequence, and total combined analyses and from MEGA5 for ERIC-PCR and REP-PCR data analyses. Bootstrap values from ML analyses or UPGMA analyses greater than $70 \%$ and posterior probabilities from MCMC analyses greater than 0.95 were included on phylogenetic trees. X. fastidiosa strain XF A-10 was not included in the ML searches or in the MCMC analysis of the total combined dataset due to a lack of sequence data.

\section{Results}

Genetic verification of $X$. fastidiosa strains isolated from pecan and other plant hosts in Louisiana. A DNA band of approximately $733 \mathrm{bp}$, the expected product size for confirmation of $X$. fastidiosa strains when using $X$. fastidiosa-specific primers RST31 and RST33, was produced from all bacterial strains isolated from pecan and other plants (grapevine, oleander, and sycamore) in Louisiana and used in this study.

Multiprimer PCR assay of $X$. fastidiosa strains isolated in Louisiana. Three DNA bands of approximately 412, 521, and 638 $\mathrm{bp}$, the expected sizes of the products amplified from the multiprimer PCR assay for $X$. fastidiosa subsp. multiplex almond leaf scorch (ALS) II genotype, were amplified from each of the pecan and sycamore strains from Louisiana (Fig. 1; data not shown for XF A-10 and XF B-10) (20). A single band of approximately 412 bp, the expected size of the product amplified from the multiprimer PCR assay for $X$. fastidiosa subsp. fastidiosa PD genotype, was amplified from the Louisiana grapevine strain, XF A-08 (Fig. 1) (20). A single band of approximately $638 \mathrm{bp}$, the expected size of the product amplified from the multiprimer PCR assay for X. fastidiosa subsp. sandyi oleander leaf scorch (OLS) genotype, was amplified from the Louisiana oleander strain, XF Oleander (Fig. 1) (20).

Sequence analyses of the 16S-23S rRNA ITS region of $X$. fastidiosa strains isolated in Louisiana. ITS sequences were obtained from nine strains of $X$. fastidiosa used in this study. ClustalW2 alignment of the ITS sequences trimmed to the same starting and ending points showed that the ITS sequences from all strains of $X$. fastidiosa from pecan and sycamore from Louisiana were identical. These strains had a sequence identity of $98 \%$ when compared with the grapevine (XF A-08) and oleander (XF Oleander) strains from Louisiana. A basic local alignment search tool (BLAST) (http://blast.ncbi.nlm.nih.gov/Blast.cgi) search of the pecan and sycamore ITS sequence against the complete genomes of $X$. fastidiosa (Table 3) showed the highest sequence identity to $X$. fastidiosa subsp. multiplex strain M12 from almond (100\%) followed by $X$. fastidiosa subsp. pauca strain 9a5c from citrus (99\%) and X. fastidiosa subsp. fastidiosa strains Temecula1 and GB514 from grapevine and M23 from almond (98\%) (5). A BLAST search of the ITS sequence from grapevine strain XF A-08 showed the highest sequence identity (100\%) to $X$. fastidiosa subsp. fastidiosa strains Temecula1 and GB514 from grapevine and M23 from almond. A BLAST search of the ITS sequence from oleander strain XF Oleander showed the highest sequence identity (99\%) to X. fastidiosa subsp. fastidiosa strains Temecula1 and GB514 from grapevine and M23 from almond. ITS sequences obtained for strains of $X$. fastidiosa in this study were deposited in
GenBank under accession numbers JN092378 through JN092386 (Table 3).

Sequence analyses of $p g l A$ of $X$. fastidiosa strains isolated in Louisiana. DNA sequences of $p g l A$ encoding a polygalacturonase, a major virulence factor of $X$. fastidiosa (43), were obtained from eight strains of $X$. fastidiosa used in this study. ClustalW2 alignment of the pglA sequences showed that the pglA sequences from all $X$. fastidiosa strains from pecan and sycamore from Louisiana were identical. These strains had a sequence identity of $98 \%$ when compared with the grapevine (XF A-08) and oleander (XF Oleander) strains from Louisiana. A BLAST search of the pecan and sycamore pglA sequence against the complete genome sequences of $X$. fastidiosa (Table 3 ) showed the highest sequence identity (99\%) to X. fastidiosa subsp. multiplex strain M12 from almond, followed by $X$. fastidiosa subsp. fastidiosa strains Temecula1 and GB514 from grapevine and M23 from almond (98\%), and $X$. fastidiosa subsp. pauca strain 9a5c from citrus (97\%). A BLAST search of the pglA sequence from grapevine strain XF A-08 showed the highest sequence identity $(100 \%)$ to $X$. fastidiosa subsp. fastidiosa strains Temecula1 and GB514 from grapevine and M23 from almond. A BLAST search of the pglA sequence from oleander strain XF Oleander showed the highest sequence identity (98\%) to $X$. fastidiosa subsp. fastidiosa strains Temecula1 and GB514 from grapevine and M23 from almond and to $X$. fastidiosa subsp. multiplex strain M12 from almond. Early termination, which is present in the pglA gene of strain $9 \mathrm{a} 5 \mathrm{c}$ from citrus (65), was not found in any of the pglA sequences from strains of $X$. fastidiosa from Louisiana. pglA sequences obtained from strains of $X$. fastidiosa in this study were deposited in GenBank under accession numbers JN092387 through JN092394 (Table 3).

Rep-PCR analyses of $X$. fastidiosa strains isolated in Louisiana. Bands in 10 band classes between 100 and 1,650 bp for ERIC-PCR and in 9 band classes between 400 and 2,000 bp for REP-PCR were scored as being present or absent for each $X$. fastidiosa strain tested.

All pecan strains, regardless of the cultivar from which they were isolated, and the sycamore strain produced the same ERICPCR fingerprint (Fig. 2A). Obvious band differences were present in the ERIC-PCR fingerprints between the grapevine and oleander strains and between these strains and those from pecan and sycamore (Fig. 2A). Namely, bands approximately 155, 550, and 880 bp in size were present only in grapevine strain XF A-08 and oleander strain XF Oleander but not in any of the other strains; bands approximately 160 and $950 \mathrm{bp}$ in size were present in all pecan strains and in sycamore strain XF A-07 but not in grapevine strain XF A-08 or oleander strain XF Oleander; bands approximately 300 and 420 bp in size were present in all strains except oleander strain XF Oleander; and a band approximately 1,275 bp in size was present in oleander strain XF Oleander but not in any of the other strains (Fig. 2A).

Obvious band differences were present in the REP-PCR fingerprints between the grapevine and oleander strains and between

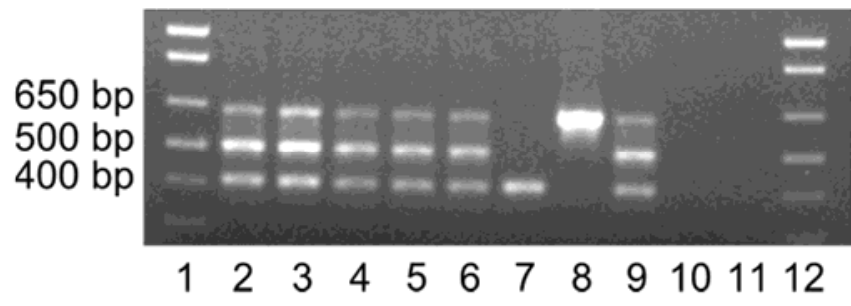

Fig. 1. Multiprimer polymerase chain reaction products of strains of Xylella fastidiosa isolated from diseased grapevine, oleander, pecan, and sycamore from Louisiana. A strain of Burkholderia glumae and sterile distilled deionized water $\left(\mathrm{ddH}_{2} \mathrm{O}\right)$ were used as negative controls. Samples were arranged as follows: lane 1: 1-kb-plus ladder (Invitrogen); lane 2: XF A-05 (pecan); lane 3: XF B-05 (pecan); lane 4: XF C-05 (pecan); lane 5: XF A-06 (pecan); lane 6: XF D-07 (pecan); lane 7: XF A-08 (grapevine); lane 8: XF Oleander (oleander); lane 9: XF A-07 (sycamore); lane 10: $B$. glumae 336gr-1; lane 11: sterile $\mathrm{ddH}_{2} \mathrm{O}$; and lane 12: 1-kb-plus ladder. 
these strains and those from pecan and sycamore (Fig. 3A). Namely, a band approximately 460 bp in size was present in all strains except grapevine strain XF A-08; a band approximately 600 $\mathrm{bp}$ in size was present only in grapevine strain XF A-08; and bands approximately 750 and 1,600 bp were present only in oleander strain XF Oleander (Fig. 3A). A band approximately 520 bp in size was present in all strains except pecan strain XF A-06, grapevine strain XF A-08, oleander strain XF Oleander, and sycamore strain
A

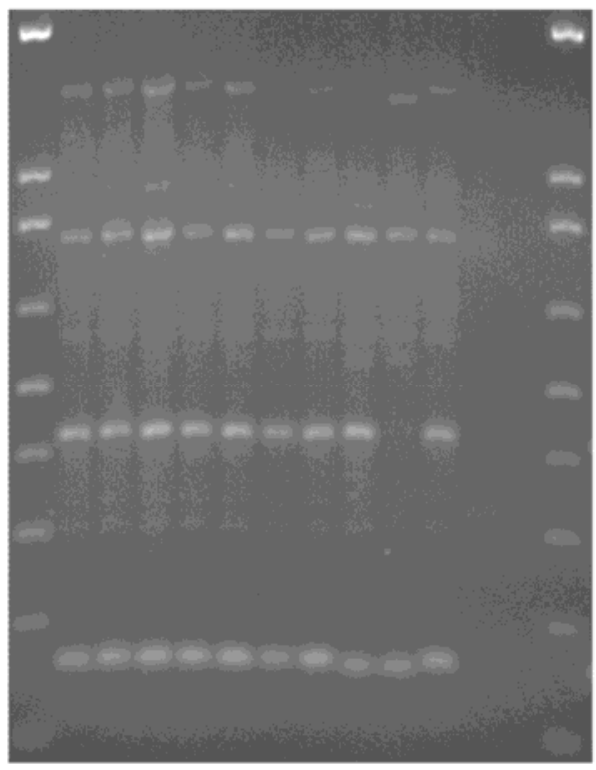

$12234 \begin{array}{lllllll} & 2 & 6 & 7 & 8 & 9 & 1011121314\end{array}$
$1650 \mathrm{bp}$

$1000 \mathrm{bp}$

$850 \mathrm{bp}$

$650 \mathrm{bp}$

$500 \mathrm{bp}$

$400 \mathrm{bp}$

$300 \mathrm{bp}$

$200 \mathrm{bp}$

$100 \mathrm{bp}$

B

Pecan cv. Cape Fear (XF A-05)

Sycamore (XF A-07)

Pecan cv. Cape Fear (XF A-06)

Pecan cv. Cape Fear (XF D-07)

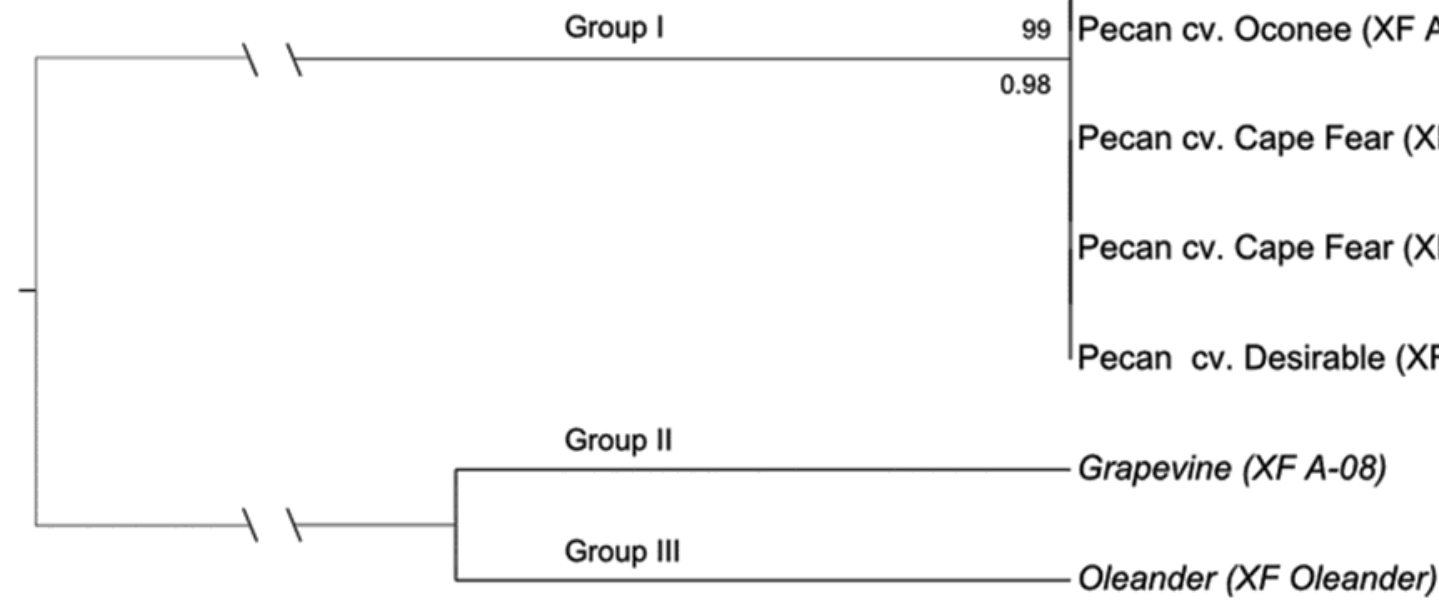

Fig. 2. A, Enterobacterial repetitive intergenic consensus polymerase chain reaction (ERIC-PCR) product fingerprints from 10 strains of $X y l e l l a$ fastidiosa isolated from diseased grapevine, oleander, pecan, and sycamore from Louisiana. Sterile distilled deionized water $\left(\mathrm{ddH}_{2} \mathrm{O}\right)$ was used as a negative control. Samples were arranged as follows: lane 1: 1-kb-plus ladder (Invitrogen); lane 2: XF A-05 (pecan, CF); lane 3: XF B-05 (pecan, CF); lane 4: XF C-05 (pecan, CF); lane 5: XF A-06 (pecan, CF); lane 6: XF D-07 (pecan, CF); lane 7: XF A-10 (pecan, 0); lane 8: XF B-10 (pecan, D); lane 9: XF A-08 (grapevine); lane 10: XF Oleander (oleander); lane 11: XF A-07 (sycamore); lane 12: Burkholderia glumae 336gr-1; lane 13: sterile $\mathrm{ddH}_{2} \mathrm{O}$; and lane 14: 1-kb-plus ladder. Pecan cultivar designations: $\mathrm{CF}=$ Cape Fear; $D=D e s i r a b l e ; ~ O=O c o n e e . ~ B$, Phylogram constructed from the ERIC-PCR fingerprints shown in A. Branch tip labels include the plant host and cultivar, when applicable, from which the strain of $X$. fastidiosa was obtained and the strain name (parentheses). Phylogram was obtained from an unweighted pair-group method with arithmetic means analysis (1,000 bootstrap replicates) using MEGA5. Bootstrap values (>70\%) are shown above branch nodes; posterior probabilities $(>0.95)$ obtained from Bayesian inference in MrBayes 3.1 are shown below branch nodes. 
XF A-07. In addition, REP-PCR fingerprints of pecan strains showed variation among some pecan strains (Fig. 3A). Pecan Cape Fear strain XF A-06 and sycamore strain XF A-07 produced a band approximately $900 \mathrm{bp}$ in size that was not present in any other strains tested. Pecan 'Oconee' strain XF A-10 failed to produce a band approximately $1,900 \mathrm{bp}$ in size that was present in all other pecan strains and in the sycamore strain but produced a slightly larger band, approximately 1,950 bp in size, that was not present in any of the other strains tested.

Phylogenetic analyses of $X$. fastidiosa strains isolated in Louisiana. Three main groups were recovered from Bayesian inference and UPGMA using the ERIC-PCR dataset (Fig. 2B).
A

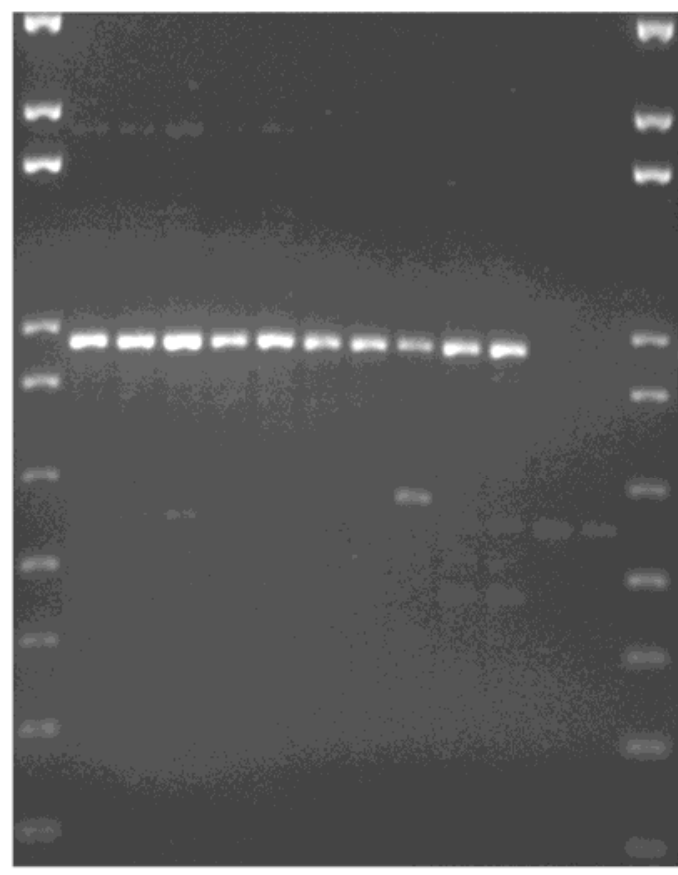

$\begin{array}{llllllllll}1 & 2 & 3 & 4 & 5 & 6 & 7 & 8 & 9 & 1011121314\end{array}$
$3000 \mathrm{bp}$

$2000 \mathrm{bp}$

$1650 \mathrm{bp}$

$1000 \mathrm{bp}$

$850 \mathrm{bp}$

$650 \mathrm{bp}$

$500 \mathrm{bp}$

$400 \mathrm{bp}$

$300 \mathrm{bp}$

$200 \mathrm{bp}$

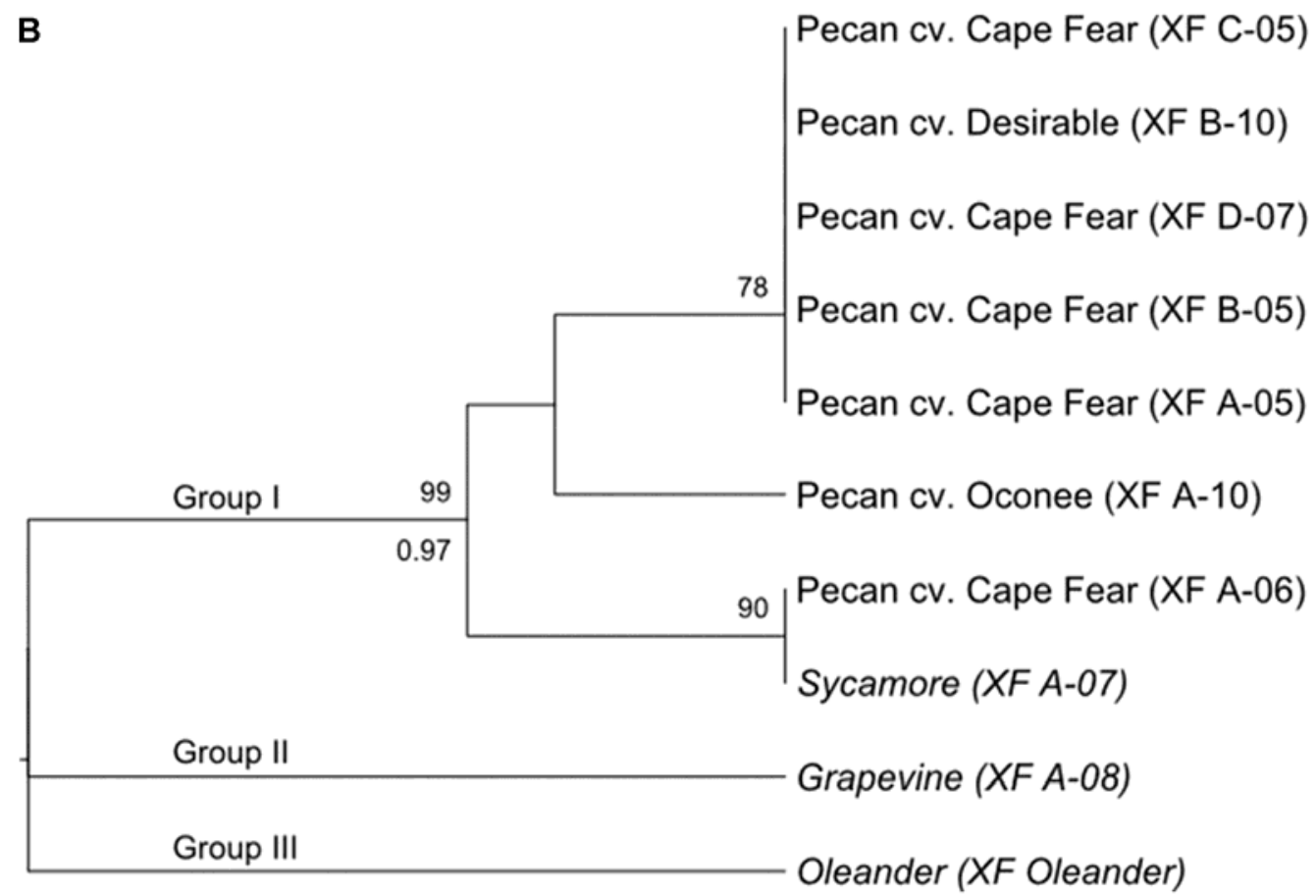

Fig. 3. A, Repetitive extragenic palindromic polymerase chain reaction (REP-PCR) product fingerprints from 10 strains of Xylella fastidiosa isolated from diseased grapevine, oleander, pecan, and sycamore from Louisiana. Sterile distilled deionized water $\left(\mathrm{ddH}_{2} \mathrm{O}\right)$ was used as a negative control. Samples were arranged as follows: lane 1: 1-kbplus ladder (Invitrogen); lane 2: XF A-05 (pecan, CF); lane 3: XF B-05 (pecan, CF); lane 4: XF C-05 (pecan, CF); lane 5: XF A-06 (pecan, CF); lane 6: XF D-07 (pecan, CF); lane 7: XF A-10 (pecan, O); lane 8: XF B-10 (pecan, D); lane 9: XF A-08 (grapevine); lane 10: XF Oleander (oleander); lane 11: XF A-07 (sycamore); lane 12: Burkholderia glumae 336gr-1; lane 13: sterile $\mathrm{ddH}_{2} \mathrm{O}$; and lane 14: 1-kb-plus ladder. Pecan cultivar designations: $\mathrm{CF}=$ Cape Fear; $\mathrm{D}=$ Desirable; $\mathrm{O}=$ Oconee. $\mathrm{B}$, Phylogram constructed from the REP-PCR fingerprints shown in A. Branch tip labels include the plant host and cultivar, when applicable, from which the strain of $X$. fastidiosa was obtained and the strain name (parentheses). Phylogram was obtained from an unweighted pair-group method with arithmetic means analysis (1,000 bootstrap replicates) using MEGA5. Bootstrap values ( $>70 \%)$ are shown above branch nodes; posterior probabilities (>0.95) obtained from Bayesian inference in MrBayes 3.1 are shown below branch nodes. 
Group I, which was well supported by Bayesian posterior probability (0.98) and UPGMA bootstrap (99\%), was monophyletic and included all strains of $X$. fastidiosa from pecan and sycamore (Fig. 2B). Group II and group III included only the grapevine strain and the oleander strain, respectively, separating each of them from all other strains.

Three main groups were recovered from Bayesian inference and UPGMA using the REP-PCR dataset (Fig. 3B). Group I, which was well supported by Bayesian posterior probability (0.97) and UPGMA bootstrap (99\%), was monophyletic and included all strains of $X$. fastidiosa from pecan and sycamore (Fig. 3B). Three subgroups, however, were present within group I: one subgroup included strain XF A-06 from pecan Cape Fear and strain XF A-07 from sycamore (UPGMA bootstrap $=90 \%$ ); the second subgroup included only strain XF A-10 from pecan Oconee; and the third subgroup included four strains from pecan Cape Fear (XF A-05, XF B-05, XF C-05, and XF D-07) and strain XF B-10 from the pecan 'Desirable' (UPGMA bootstrap $=78 \%$; Fig. 3B). Group II and group III included only the grapevine strain and the oleander strain, respectively, separating each of them from all other strains.

A UPGMA phylogram recovered from the combined ERIC-PCR and REP-PCR datasets was similar to the REP-PCR UPGMA phylogram, with similar support from bootstrap values and posterior probabilities, except that it showed the pecan-sycamore subgroup to be more closely related to the larger pecan subgroup (data not shown).

The ML phylogram of aligned and cured 16S-23S ITS regions from 49 strains of $X$. fastidios $a$ and one strain of $X$. campestris $p v$. campestris included as an outgroup placed the majority of the $X$. fastidiosa strains into six major monophyletic or paraphyletic groups, with bootstrap values greater than $84 \%$ (Fig. 4). The majority of these groups were also strongly supported by posterior probabilities greater than 0.95 . Group I was monophyletic and included strains from citrus and coffee. Group II was paraphyletic, with unresolved relationships among strains from a variety of hosts, including the pecan and sycamore strains from Louisiana and strains from almond and peach. Group III was a monophyletic group within group II and included strains of $X$. fastidiosa from chitalpa (40). Group IV was a monophyletic group also recovered within group II that included strains of $X$. fastidiosa from oak. Group V was monophyletic and included strains of $X$. fastidiosa from oleander, including the Louisiana oleander strain. Group VI was monophyletic and included strains of $X$. fastidiosa from almond and grapevine, including the Louisiana grapevine strain.

The ML analysis of the aligned pglA sequences from 13 strains of $X$. fastidiosa, including citrus strain $9 \mathrm{a} 5 \mathrm{c}$ used as an outgroup, separated the strains into four groups (Fig. 5). The pecan and sycamore strains formed a monophyletic group with $X$. fastidiosa subsp. multiplex strain M12 from almond. The Louisiana grapevine strain formed a monophyletic group with strains of $X$. fastidiosa subsp. fastidiosa from grapevine and almond. The Louisiana oleander strain formed a separate group distinct from all other strains of $X$. fastidiosa. X. fastidiosa subsp. pauca strain 9a5c from citrus also formed a group distinct from all other strains of $X$. fastidiosa. Most of the major groups were strongly supported, with bootstrap values greater than $85 \%$ and posterior probabilities of 0.99 (Fig. 5).

The MCMC analysis of the total combined dataset of 49 strains of $X$. fastidiosa and one strain of $X$. campestris pv. campestris, including the aligned and cured ITS sequences, the aligned pglA sequences, and the binary data from ERIC-PCR and REP-PCR, placed the majority of the $X$. fastidiosa strains into six major monophyletic or paraphyletic groups, with bootstrap values greater than $84 \%$ (Fig. 6). Though the location of groups on the phylogram differed in comparison with the phylogram recovered from the cured ITS sequences (Fig. 4), the different monophyletic and paraphyletic groups in this analysis comprised the same strains of

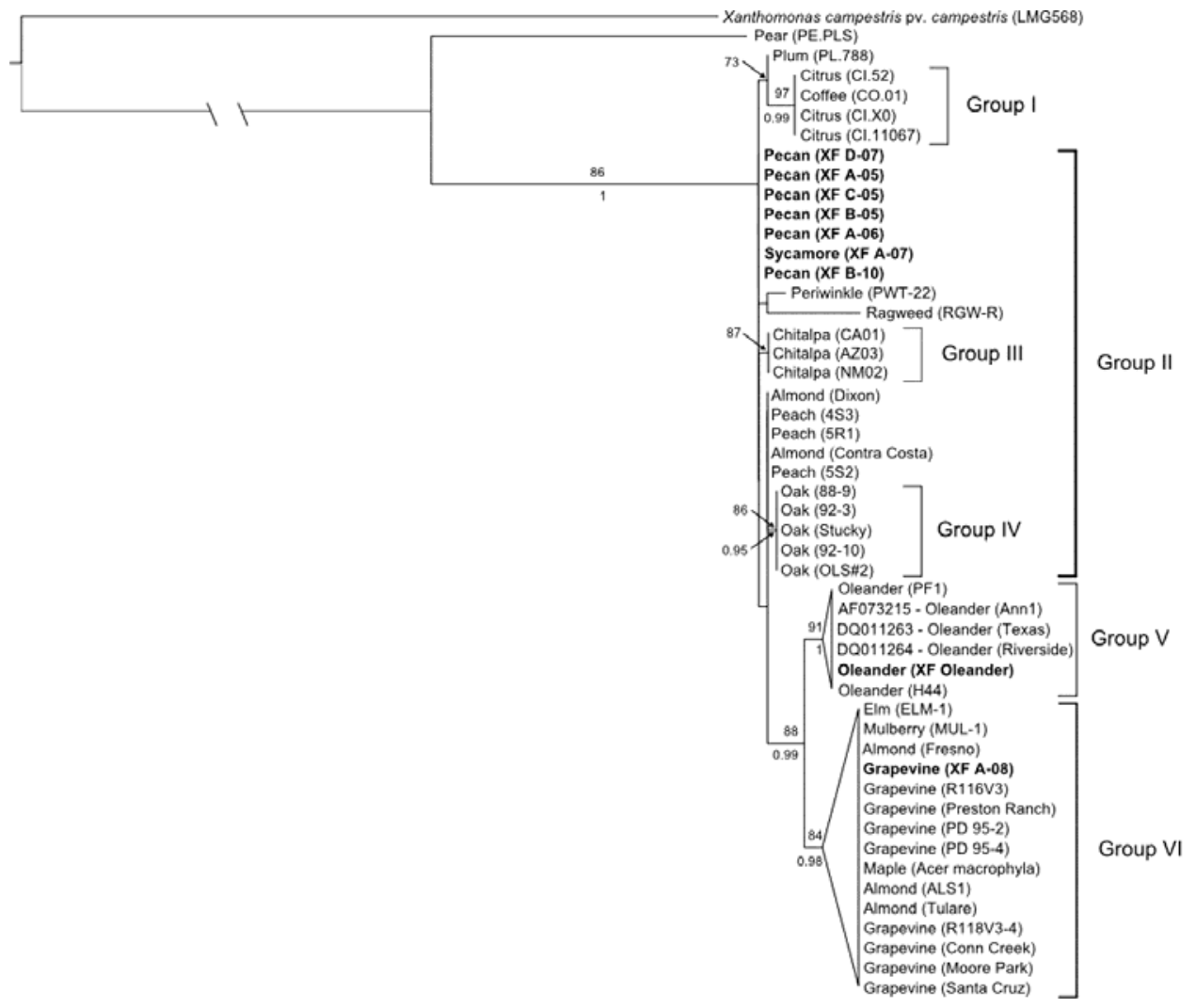

Fig. 4. Phylogram of the 16S-23S rRNA intergenic transcribed spacer (ITS) dataset from 49 strains of Xylella fastidiosa and one strain of Xanthomonas campestris pv. campestris included as an outgroup. Branch tip labels include the host and strain name (parentheses) of $X$. fastidiosa. ITS sequences obtained from this study are indicated in bold. Sequences from all other strains were obtained from the National Center for Biotechnology Information GenBank. Phylogram was obtained from a maximum likelihood (ML) search using RAxML. Bootstrap values (>70\%) from 1,000 bootstrap replicates from the ML search are shown above branch nodes; posterior probabilities (>0.95) obtained from Bayesian inference in MrBayes 3.1 are shown below branch nodes. 
$X$. fastidiosa as the previous analysis. The pecan and sycamore strains were still part of a large paraphyletic group that included other strains of $X$. fastidiosa from almond and peach. This analysis showed increased posterior probability support for a number of groups (Fig. 6).

Convergence of all Bayesian analyses was verified using the cumulative and compare functions in AWTY.

\section{Discussion}

$X$. fastidiosa is a complex plant pathogen that infects and causes disease in a wide range of hosts (38). Subspecies classifications have been based largely on molecular techniques and host plant infectivity. However, genetic differences within subspecies and even within strains from the same host have also been observed $(2,32,53)$. Recombination has also been shown to occur between subspecies and between strains from different hosts $(2,53,57)$. The presence of multiple subspecies and strains of $X$. fastidiosa in the same geographic region with common insect vectors may increase the opportunity for continuing diversification within this species and the possibility of the occurrence of new diseases in hosts that have yet to be infected by $X$. fastidiosa (35).

Pecan is the only nut grown commercially in the United States that is also native to the United States (37). It is produced in 15 states (Agricultural Statistics 2010, United States Department of Agriculture NASS), including California, New Mexico, Texas, Louisiana, Georgia, and Florida, where diseases caused by X. fastidiosa have been reported and are known to occur $(23,40)$. However, pecan strains of $X$. fastidiosa have rarely been studied and, consequently, their genetic and taxonomic information is very limited. In this investigation, various molecular techniques and phylogenetic methods were used to study the taxonomy of $X$. fastidiosa strains isolated from pecan and other plant hosts in Louisiana at a subspecific level. To our knowledge, this is the first phylogenetic study focused on $X$. fastidiosa strains from pecan and from Louisiana.

The multiprimer PCR assay identified strains of X. fastidiosa from Louisiana by genotype and subspecies (Fig. 1). The amplification of three products from the multiprimer PCR assay indi- cated that strains of $X$. fastidiosa from pecan and sycamore are of the ALSII genotype from $X$. fastidiosa subsp. multiplex (Fig. 1) (20). ALSII strains from almond can infect and produce mild symptoms in grapevine, whereas ALSI strains from almond, identified by the amplification of two products in the multiprimer PCR assay, cannot cause disease in grapevine (20). A limitation of the multiprimer PCR assay concerning $X$. fastidiosa subsp. multiplex is that it was designed using only strains of $X$. fastidiosa from almond, grapevine, and oleander. Even though the pecan and sycamore strains are of the ALSII genotype, this does not necessarily mean that these strains can infect grapevine. Host-plant inoculations that should determine the relevance of the pecan strains as an ALSII genotype are currently being conducted. The multiprimer PCR assay identified the grapevine strain from Louisiana as the PD genotype of $X$. fastidiosa subsp. fastidiosa and the oleander strain from Louisiana as the OLS genotype of $X$. fastidiosa subsp. sandy $i$ (Fig. 1).

Sequence analysis of the 16S-23S rRNA ITS region has been used in previous studies to identify strains of $X$. fastidiosa below the species level and was applied to the strains in this study $(26,31,33)$. The pecan and sycamore ITS sequences were identical and most similar to other $X$. fastidiosa subsp. multiplex strains. The ITS sequence of the Louisiana grapevine strain was identical to that of strains Temecula1 and GB514 from grapevine and strain M23 from almond, which are all strains of $X$. fastidiosa subsp. fastidiosa. Our observation that the ITS sequences of pecan strains were identical to each other and the ITS sequence of the grapevine strain was identical to that of the grapevine strains from the completely sequenced strains was not surprising because a previous study showed that, with the exception of almond strains, all strains from the same host had the same ITS sequence (19). Phylogenetic analysis of the ITS region supported the subspecies groups determined from the multiprimer PCR assay (Figs. 1 and 4). In addition, the major groups of $X$. fastidiosa strains identified in this study were consistent with groups from previous phylogenetic analyses based on ITS sequences, with the exception that the strains from chitalpa formed a monophyletic group within the unresolved subspecies multiplex group (Fig. 4) $(19,31,33)$.

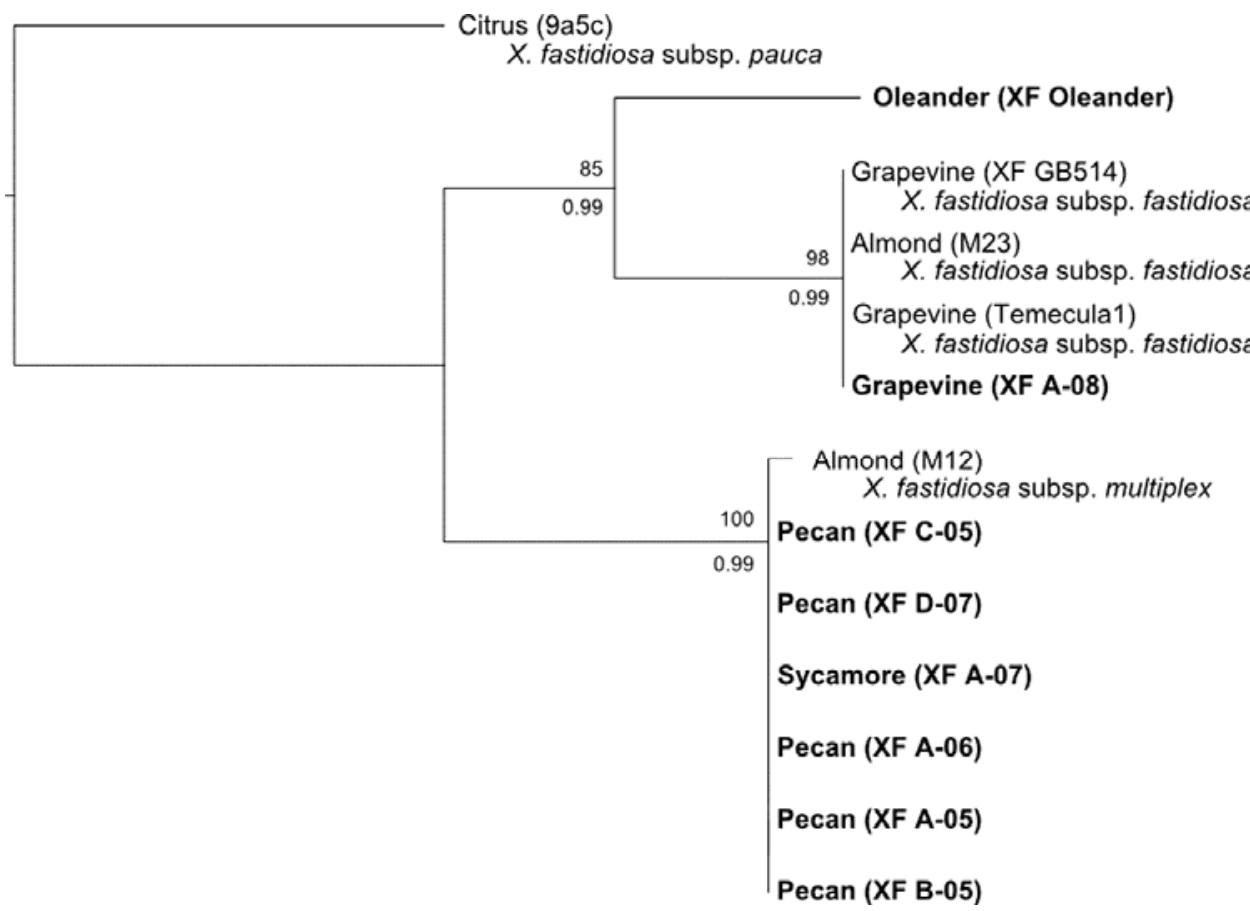

Fig. 5. Phylogram of pglA sequences from 13 strains of Xylella fastidiosa with the citrus strain 9a5c used as an outgroup. Branch tip labels include the host strain name (parentheses) of $X$. fastidiosa; the known subspecies of $X$. fastidiosa are indicated below each branch tip label. pglA sequences obtained from this study are indicated in bold. Sequences from all other strains were obtained from the National Center for Biotechnology Information GenBank. Phylogram was obtained from a maximum likelihood (ML) search using RAxML. Bootstrap values (>70\%) from 1,000 bootstrap replicates from the ML search are shown above branch nodes; posterior probabilities (>0.95) obtained from Bayesian inference in MrBayes 3.1 are shown below branch nodes. 
A frameshift causing early termination in the polygalacturonase precursor gene, $p g l A$, that is present in citrus and coffee strains of $X$. fastidiosa (65) was not found in pglA of pecan, grapevine, oleander, or sycamore strains from Louisiana. This frameshift was also not present in almond, grapevine, mulberry, or oleander strains in the study that reported the frameshift from citrus and coffee strains (65). It was suggested that this frameshift possibly made pglA nonfunctional and accounted for the less-aggressive nature of citrus variegated chlorosis strains compared with PD strains of $X$. fastidiosa $(3,65)$. Polygalacturonase has been shown to be required for colonization and pathogenicity in grapevine but is not necessary for the development of disease in citrus $(43,65)$. Despite the absence of a frameshift in pglA of X. fastidiosa pecan, oleander, and sycamore strains, it is unknown whether this gene is required for colonization and pathogenicity of these strains. As with the ITS sequences, all pglA sequences from pecan and sycamore were identical. These sequences were more closely related to the $X$. fastidiosa subsp. multiplex strain than to any other subspecies. The $p g l A$ sequence from grapevine in Louisiana was identical to $p g l A$ sequences from the $X$. fastidiosa subsp. fastidiosa Temecula1 and GB514 grapevine strains. Sequence analysis of $p g l A$ separated strains of $X$. fastidiosa into the same subspecies groups as the multiprimer PCR assay, providing further support for these groups (Figs. 1 and 5).

ERIC-PCR and REP-PCR separated the Louisiana pecan and sycamore strains from the Louisiana grapevine strain and the Louisiana oleander strain (Figs. 2 and 3). REP-PCR detected ge- netic differences within the strains of $X$. fastidiosa from pecan while ERIC-PCR failed to detect any differences (Figs. 2 and 3) Similar results were reported for $X$. fastidiosa strains from citrus, in which REP-PCR banding patterns were more discriminative than the ERIC-PCR banding patterns (32). Although the differences in the citrus strain REP-PCR profiles corresponded to differences in geographic location in a previous study (32), differences in the strains of $X$. fastidiosa from pecan were observed within the same geographic location and the same cultivar in this study (Table 1; Fig. 3). In the REP-PCR, one of the five pecan strains from Cape Fear, XF A-06, clustered with and was more closely related to the sycamore strain, XF A-07, than to the other pecan strains (Fig. 3). This subgroup was more related to the pecan strain from Oconee, XF A-10, than to the subgroup containing four other pecan strains from Cape Fear (XF A-05, XF B-05, XF C-05, and XF D-07) and the pecan strain from Desirable, XF B-10 (Fig. 3). Although we do not know whether the genetic differences observed here relate to any biological traits, these results suggest that there might be some level of specialization within $X$. fastidiosa subsp. multiplex related to pecan cultivar.

The phylogenetic analysis of the combined dataset of the ITS sequences, pglA sequences, and ERIC-PCR and REP-PCR data strengthened support for a number of groups identified in this study but did not place the pecan strains in a separate monophyletic group within the $X$. fastidiosa subsp. multiplex group (Fig. 6). Additional strains from pecan and other hosts and additional genetic information

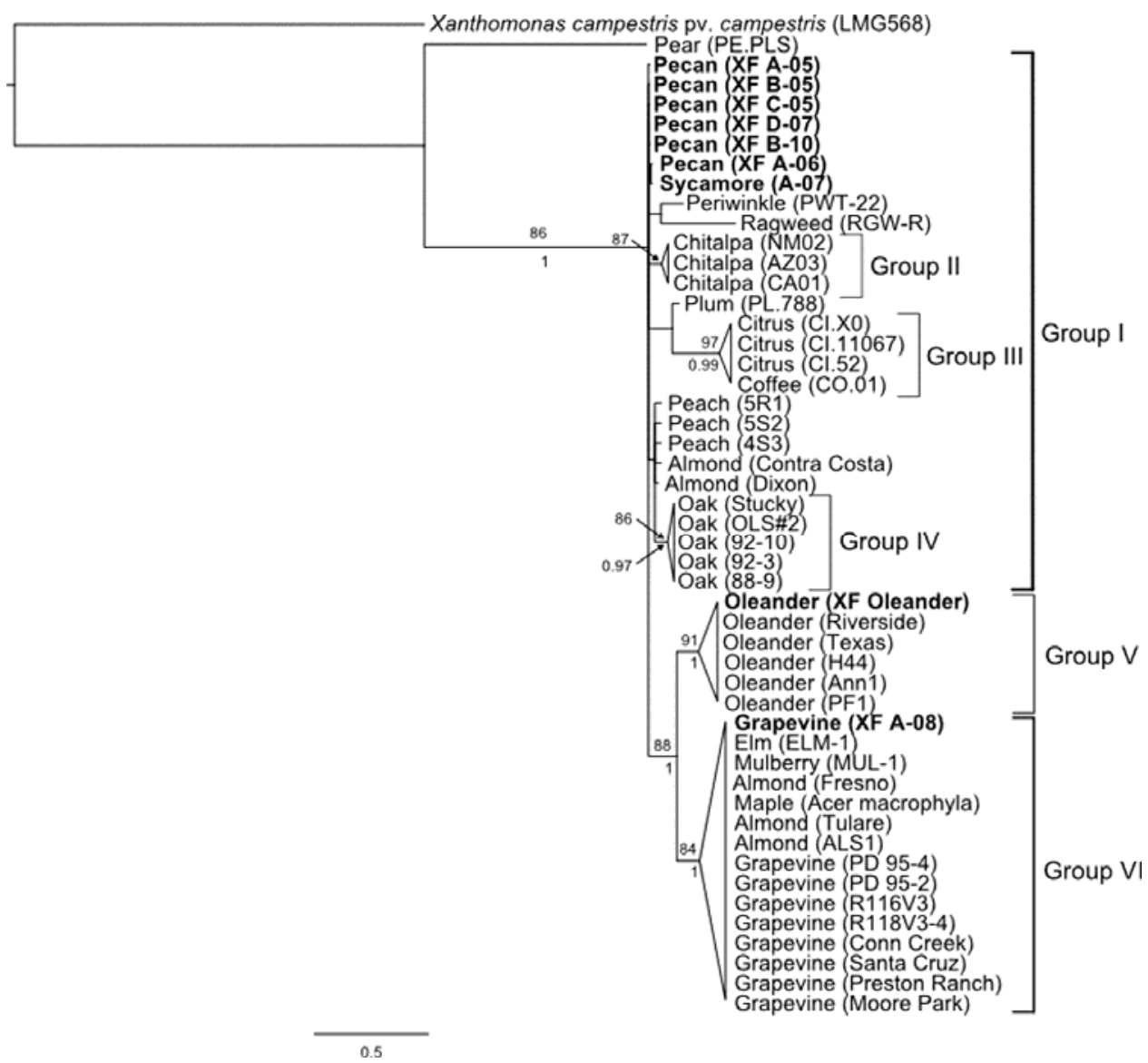

Fig. 6. Phylogram of the combined dataset constructed from available 16S-23S rRNA intergenic transcribed spacer (ITS) sequences, pglA sequences, and enterobacterial repetitive intergenic consensus polymerase chain reaction (ERIC-PCR) and repetitive extragenic palindromic (REP)-PCR product fingerprints from 49 strains of Xylella fastidiosa and one strain of Xanthomonas campestris pv. campestris included as an outgroup. Pecan strain XF A-10 was not included in the analysis due to a lack of sequence data. Because $p g I A$ sequences were only available for strains whose complete genomes have been published, these sequences were included with the ITS sequences in the combined dataset as follows: 9a5c pglA sequence included with strain CI.X0; Temecula1 pglA sequence included with strain PD 95-2; GB514 pgIA sequence included with strain PD 95-4; M12 pglA sequence included with strain Dixon; and M23 pglA sequence included with strain ALS1. Branch tip labels include the plant host from which the strain of $X$. fastidiosa was obtained and the strain name (parentheses). ITS sequences, ERIC-PCR, and REP-PCR data obtained from this study are indicated in bold. Sequences from all other strains were obtained from GenBank. Phylogram was obtained from Bayesian analysis in MrBayes 3.1. Bootstrap values (>70\%) from 1,000 bootstrap replicates from the maximum likelihood search in RAxML of the 16S-23S ITS sequences cured in Gblocks are shown above branch nodes; posterior probabilities (>0.95) obtained from the Bayesian inference of the combined data set in MrBayes 3.1 are shown below branch nodes. 
may be necessary to distinguish the pecan strains as a separate monophyletic group. A multilocus sequence typing analysis, which identified different clonal complexes within $X$. fastidiosa subsp. multiplex (53), may be able to identify a new clonal complex for pecan strains or may group pecan strains with other similar strains, possibly sycamore strains, based on this study (Fig. 6).

Results from the various experiments conducted in this study consistently grouped the strains of $X$. fastidiosa from pecan together with each other and with the strain of $X$. fastidiosa from sycamore from Louisiana and as part of a larger group that included strains of $X$. fastidiosa subsp. multiplex from other host plants. For this reason, strains of $X$. fastidiosa from pecan should be considered a part of $X$. fastidiosa subsp. multiplex. This placement is also supported by the findings of Su et al. (63). In addition, the analyses conducted in this study placed the Louisiana grapevine strain with other grapevine strains from $X$. fastidiosa subsp. fastidiosa and the Louisiana oleander strain with other oleander strains from $X$. fastidiosa subsp. sandyi.

Studies on PBLS incidence in the research orchards at the Pecan Research-Extension Station have shown consistent disease spread within some cultivars (48). Disease severity and rate of spread also differ between pecan cultivars. Even though the majority of the pecan strains utilized in this study came from a single location and from a single cultivar, genetic variation was detected within these strains. The genetic differences observed between strains of $X$. fastidiosa from pecan from the same location and from the same cultivar in the REP-PCR suggest that these strains may not be clones originating from a single source of infection. However, it cannot be ruled out that some mutation occurred to cause the genetic variation seen in the REP-PCR while a single strain spread throughout the orchards. To determine the biological meaning of these observed genetic variations within the pecan strains of $X$. fastidiosa, additional studies including host specificity tests with different plant hosts and pecan cultivars are needed.

One of the difficulties in working with $X$. fastidiosa is that it is very fastidious and slow growing. Isolation attempts from pecan over several years have had low success rates and yielded few strains. Concentrated efforts should be made to build a collection of $X$. fastidiosa pecan strains suitable for future studies.

This work provides a foundation for studies with additional strains of $X$. fastidiosa from Louisiana to determine variation that exists in this widespread pathogen within Louisiana and other states of the southeastern United States. Continuation of this study for examining new diseases caused by $X$. fastidios $a$ and the genetic diversification within $X$. fastidiosa will provide a better understanding of the population dynamics of this pathogen and a useful insight into the development of effective management strategies for plant diseases caused by this pathogen. Potential future research areas that are important for developing new disease control strategies would include identification of alternative hosts that could serve as reservoirs of inoculum for different $X$. fastidiosa subspecies and determination of genetic factors that contribute to host specificity, pathogenicity, and virulence. With the knowledge obtained from studying these research areas, disease management guidelines in terms of what other plants can be grown in the vicinity of crop growing areas without cross-infection between different hosts could be established. In addition, diagnosis and quarantine systems for plant diseases caused by various subgroups of $X$. fastidiosa could be significantly improved by the development of more reliable and specific molecular markers based on better knowledge of genetic diversity within $X$. fastidiosa.

\section{Acknowledgments}

This research was supported by funding from the Louisiana State University Agricultural Center. We thank R. Singh and D. Ferrin for the use of the strain of $X$. fastidiosa from oleander in Louisiana and D. Ferrin for critical review of this manuscript.

\section{Literature Cited}

1. Adlerz, W. C., and Hopkins, D. L. 1979. Natural infectivity of two sharpshooter vectors of Pierce's disease of grape in Florida. J. Econ. Entomol.
72:916-919.

2. Almeida, R. P., Nascimento, F. E., Chau, J., Prado, S. S., Tsai, C. W., Lopes, S. A., and Lopes, J. R. 2008. Genetic structure and biology of Xylella fastidiosa strains causing disease in citrus and coffee in Brazil. Appl. Environ. Microbiol. 74:3690-3701.

3. Almeida, R. P. P., Pereira, E. F., Purcell, A., and Lopes, J. R. S. 2001. Multiplication and movement of a citrus strain of Xylella fastidiosa within sweet orange. Plant Dis. 85:382-386.

4. Almeida, R. P. P., and Purcell, A. H. 2003. Homalodisca coagulata (Hemiptera, Cicadellidae) transmission of Xylella fastidiosa to almond. Plant Dis. 87:1255-1259.

5. Altschul, S. F., Gish, W., Miller, W., Myers, E. W., and Lipman, D. J. 1990 Basic local alignment search tool. J. Mol. Biol. 215:403-410.

6. Chang, C. J., Garnier, M., Zreik, L., Rossetti, V., and Bové, J. M. 1993. Culture and serological detection of the xylem-limited bacterium causing citrus variegated chlorosis and its identification as a strain of Xylella fastidiosa. Curr. Microbiol. 27:137-142.

7. Chatterjee, S., Almeida, R. P., and Lindow, S. 2008. Living in two worlds: the plant and insect lifestyles of Xylella fastidiosa. Annu. Rev. Phytopathol. 46:243-271.

8. Chen, J., Groves, R., Civerolo, E. J., Viveros, M., Freeman, M., and Zheng, Y. 2005. Two Xylella fastidiosa genotypes associated with almond leaf scorch disease on the same location in California. Phytopathology 95:708714.

9. Chen, J., Xie, G., Han, S., Chertkov, O., Sims, D., and Civerolo, E. L. 2010. Whole genome sequences of two Xylella fastidiosa strains (M12 and M23) causing almond leaf scorch disease in California. J. Bacteriol. 192:4534.

10. Chenna, R., Sugawara, H., Koike, T., Lopez, R., Gibson, T. J., Higgins, D. G., and Thompson, J. D. 2003. Multiple sequence alignment with the Clustal series of programs. Nucleic Acids Res. 31:3497-3500.

11. Costa, H. S., Raetz, E., Pinckard, T. R., Gispert, C., Hernandez-Martinez, R. Dumenyo, C. K., and Cooksey, D. A. 2004. Plant hosts of Xylella fastidiosa in and near southern California vineyards. Plant Dis. 88:1255-1261.

12. Damsteegt, V. D., Brlansky, R. H., Phillips, P. A., and Avijit, R. 2006 Transmission of Xylella fastidiosa, causal agent of Citrus Variegated Chlorosis, by the glassy-winged sharpshooter, Homalodisca coagulata. Plant Dis. 90:567-570.

13. Davis, M. J., French, W. J., and Schaad, N. W. 1981. Axenic culture of the bacteria associated with phony disease of peach and plum leaf scald. Curr. Microbiol. 6.

14. Davis, M. J., Purcell, A. H., and Thomson, S. V. 1978. Pierce's disease of grapevines-isolation of causal bacterium. Science 199:75-77.

15. Dereeper, A., Guignon, V., Blanc, G., Audic, S., Buffet, S., Chevenet, F., Dufayard, J.-F., Guindon, S., Lefort, V., Lescot, M., Claverie, J.-M., and Gascuel, O. 2008. Phylogeny.fr: robust phylogenetic analysis for the nonspecialist. Nucleic Acids Res. 36:W465-W469.

16. Drummond, A. J., Ashton, B., Buxton, S., Cheung, M., Cooper, A., Duran, C., Field, M., Heled, J., Kearse, M., Markowitz, S., Moir, R., Stones-Havas, S., Sturrock, S., Thierer, T., and Wilson, A. 2011. Geneious v5.4. http://www.geneious.com/.

17. Gasteiger, E., Gattiker, A., Hoogland, C., Ivanyi, I., Appel, R. D., and Bairoch, A. 2003. ExPASy: the proteomics server for in-depth protein knowledge and analysis. Nucleic Acids Res. 31:3784-3788.

18. Gonçalves, E. R., and Rosato, Y. B. 2002. Phylogenetic analysis of Xan thomonas species based upon 16S-23S rDNA intergenic spacer sequences. Int. J. Syst. Evol. Microbiol. 52:355-361.

19. Hendson, M., Purcell, A. H., Chen, D. Q., Smart, C., Guilhabert, M., and Kirkpatrick, B. 2001. Genetic diversity of Pierce's disease strains and other pathotypes of Xylella fastidiosa. Appl. Environ. Microbiol. 67:895-903.

20. Hernandez-Martinez, R., Costa, H. S., Dumenyo, C. K., and Cooksey, D. A. 2006. Differentiation of strains of Xylella fastidiosa infecting grape, almonds, and oleander using a multiprimer PCR assay. Plant Dis. 90:13821388 .

21. Hernandez-Martinez, R., de la Cerda, K. A., Costa, H. S., Cooksey, D. A., and Wong, F. P. 2007. Phylogenetic relationships of Xylella fastidiosa strains isolated from landscape ornamentals in southern California. Phytopathology 97:857-864.

22. Hopkins, D. L. 1989. Xylella fastidiosa: xylem-limited bacterial pathogen of plants. Annu. Rev. Phytopathol. 27:271-290.

23. Hopkins, D. L., and Purcell, A. H. 2002. Xylella fastidisoa: cause of Pierce's disease of grapevine and other emergent diseases. Plant Dis. 86:1056-1066.

24. Huang, Q. 2009. Specific detection and identification of Xylella fastidiosa strains causing oleander leaf scorch using polymerase chain reaction. Curr. Microbiol. 58:393-398.

25. Huelsenbeck, J. P., and Ronquist, F. 2001. MRBAYES: Bayesian inference of phylogeny. Bioinformatics 17:754-755.

26. Jensen, M. A., Webster, J. A., and Straus, N. 1993. Rapid identification of bacteria on the basis of polymerase chain reaction-amplified ribosomal DNA spacer polymorphisms. Appl. Environ. Microbiol. 59:945-952.

27. Larget, B., and Simon, D. 1999. Markov chain Monte Carlo algorithms for the Bayesian analysis of phylogenetic trees. Mol. Biol. Evol. 16:750-759.

28. Leininger, T. D. 2004. The glassy-winged sharpshooter transmits Xylella fastidiosa between sycamore trees. (Abstr.) Phytopathology 94:S59. 
29. Li, B., Sanderlin, R. S., Melanson, R. A., and Yu, Q. 2010. Spatial analysis of a plant disease in non-uniform crop: a Monte Carlo approach. J. Appl. Stat. 38:175-182.

30. Li, W. B., Pria, W. D., Lacava, P. M., Qin, X., and Hartung, J. S. 2003. Presence of Xylella fastidiosa in sweet orange fruit and seeds and its transmission to seedlings. Phytopathology 93:953-958.

31. Martinati, J. C., Pacheco, F. T., de Miranda, V. F., and Tsai, S. M. 2005. Phylogenetic relationships of Xylella fastidiosa strains based on 16S-23S rDNA sequences. Curr. Microbiol. 50:190-195.

32. Mehta, A., Leite Jr., R. P., and Rosato, Y. B. 2001. Assessment of the genetic diversity of Xylella fastidiosa isolated from citrus in Brazil by PCRRFLP of the 16S rDNA and 16S-23S intergenic spacer and rep-PCR fingerprinting. Antonie Leeuwenhoek 79:53-59.

33. Mehta, A., and Rosato, Y. B. 2001. Phylogenetic relationships of Xylella fastidiosa strains from different hosts, based on 16S rDNA and 16S-23S intergenic spacer sequences. Int. J. Syst. Evol. Microbiol. 51:311-318.

34. Minsavage, G. V., Thompson, C. M., Hopkins, D. L., Leite, R. M. V. B. C., and Stall, R. E. 1994. Development of a polymerase chain reaction protocol for detection of Xylella fastidiosa in plant tissue. Phytopathology 84:456461.

35. Nunney, L., Yuan, X., Bromley, R., Hartung, J., Montero-Astúa, M., Moreira, L., Ortiz, B., and Stouthamer, R. 2010. Population genomic analysis of a bacterial plant pathogen: novel insight into the origin of Pierce's disease of grapevine in the U.S. PLoS ONE 5:e15488.

36. Nylander, J. A. A., Wilgenbusch, J. C., Warren, D. L., and Swofford, D. L. 2008. AWTY: a system for graphical exploration of MCMC convergence in Bayesian phylogenetic inference. Bioinformatics 24:581-583.

37. Perez, A., and Pollack, S. 2003. Fruit and Tree Nuts Outlook May 28, 2003. FTS-304. U.S. Dep. Agric.-ERS.

38. Purcell, A. H., and Hopkins, D. L. 1996. Fastidious xylem-limited bacterial plant pathogens. Annu. Rev. Phytopathol. 34:131-151.

39. Purcell, A. H., Saunders, S. R., Hendson, M., Grebus, M. E., and Henry, M. J. 1999. Causal Role of Xylella fastidiosa in Oleander Leaf Scorch Disease. Phytopathology 89:53-58.

40. Randall, J. J., Goldberg, N. P., Kemp, J. D., Radionenko, M., French, J. M., Olsen, M. W., and Hanson, S. F. 2009. Genetic analysis of a novel Xylella fastidiosa subspecies found in the southwestern United States. Appl. Environ. Microbiol. 75:5631-5638.

41. Redak, R. A., Purcell, A. H., Lopes, J. R., Blua, M. J., Mizell, R. F., III, and Andersen, P. C. 2004. The biology of xylem fluid-feeding insect vectors of Xylella fastidiosa and their relation to disease epidemiology. Annu. Rev. Entomol. 49:243-270.

42. Ronquist, F., and Huelsenbeck, J. P. 2003. MRBAYES 3: Bayesian phylogenetic inference under mixed models. Bioinformatics 19:1572-1574.

43. Roper, M. C., Greve, L. C., Warren, J. G., Labavitch, J. M., and Kirkpatrick, B. C. 2007. Xylella fastidiosa requires polygalacturonase for colonization and pathogenicity in Vitis vinifera grapevines. Mol. Plant-Microbe Interact. 20:411-419.

44. Sambrook, J., and Russell, D. W. 2001. Molecular Cloning: A Laboratory Manual, 3rd ed. Cold Spring Harbor Laboratory Press, Cold Spring Harbor, NY.

45. Sanderlin, R. S. 2005. Cultivar and seedling susceptibility to pecan bacterial leaf scorch caused by Xylella fastidiosa and graft transmission of the pathogen. Plant Dis. 89:446-449.

46. Sanderlin, R. S., and Heyderich-Alger, K. I. 2000. Evidence that Xylella fastidiosa can cause leaf scorch disease of pecan. Plant Dis. 84:1282-1286.

47. Sanderlin, R. S., and Heyderich-Alger, K. I. 2003. Effects of pecan bacterial leaf scorch on growth and yield components of cultivar Cape Fear. Plant Dis. 87:259-262.

48. Sanderlin, R. S., Li, B., Melanson, R. A., and Gil, S. 2009. Spread of Xylella fastidiosa in a pecan orchard and presence of potential vectors in orchards. (Abstr.) Phytopathology 99:S114.

49. Sanderlin, R. S., and Melanson, R. A. 2006. Transmission of Xylella fastidiosa through pecan rootstock. HortScience 41:1455-1456.

50. Sanderlin, R. S., and Melanson, R. A. 2007. Pecan bacterial leaf scorch: a new look at an old problem. La. Agric. 50:23-24.

51. Sanderlin, R. S., and Melanson, R. A. 2008. Reduction of Xylella fastidiosa transmission through pecan scion wood by hot-water treatment. Plant Dis. 92:1124-1126.

52. Sanderlin, R. S., and Melanson, R. A. 2010. Insect transmission of Xylella fastidiosa to pecan. Plant Dis. 94:465-470.

53. Scally, M., Schuenzel, E. L., Stouthamer, R., and Nunney, L. 2005. Multilocus sequence type system for the plant pathogen Xylella fastidiosa and relative contributions of recombination and point mutation to clonal diversity. Appl. Environ. Microbiol. 71:8491-8499.

54. Schaad, N. W., Postnikova, E., Lacy, G., Fatmi, M. B., and Chang, C. J. 2004. Xylella fastidiosa subspecies: X. fastidiosa subsp. piercei, subsp. nov., $X$. fastidiosa subsp. multiplex subsp. nov., and X. fastidiosa subsp. pauca subsp. nov. Syst. Appl. Microbiol. 27:290-300

55. Schaad, N. W., Postnikova, E., Lacy, G., Fatmi, M., and Chang, C. J. 2004 Xylella fastidiosa subspecies: $X$. fastidiosa subsp. piercei subsp. nov., $X$ fastidiosa subsp. multiplex subsp. nov., and $X$. fastidiosa subsp. pauca subsp. nov. (Erratum). Syst. Appl. Microbiol. 27:763.

56. Schreiber IV, H. L., Koirala, M., Lara, A., Ojeda, M., Dowd, S. E., Bextine, B., and Morano, L. 2010. Unraveling the first Xylella fastidiosa subsp. fastidiosa genome from Texas. Southwest Entomol. 35:479-483.

57. Schuenzel, E. L., Scally, M., Stouthamer, R., and Nunney, L. 2005. A multigene phylogenetic study of clonal diversity and divergence in North American strains of the plant pathogen Xylella fastidiosa. Appl. Environ. Microbiol. 71:3832-3839.

58. Sherald, J. L., Hearon, S. S., Kostka, S. J., and Morgan, D. L. 1983. Sycamore leaf scorch: culture and pathogenicity of fastidious xylem-limited bacteria from scorch-affected trees. Plant Dis. 67:849-852.

59. Simpson, A. J., Reinach, F. C., Arruda, P., Abreu, F. A., Acencio, M., Alvarenga, R., Alves, L. M., Araya, J. E., Baia, G. S., Baptista, C. S., Barros, M. H., Bonaccorsi, E. D., Bordin, S., Bove, J. M., Briones, M. R., Bueno, M. R., Camargo, A. A., Camargo, L. E., Carraro, D. M., Carrer, H., Colauto, N. B., Colombo, C., Costa, F. F., Costa, M. C., Costa-Neto, C. M., Coutinho, L. L., Cristofani, M., Dias-Neto, E., Docena, C., El-Dorry, H., Facincani, A. P., Ferreira, A. J., Ferreira, V. C., Ferro, J. A., Fraga, J. S. Franca, S. C., Franco, M. C., Frohme, M., Furlan, L. R., Garnier, M., Goldman, G. H., Goldman, M. H., Gomes, S. L., Gruber, A., Ho, P. L., Hoheisel, J. D., Junqueira, M. L., Kemper, E. L., Kitajima, J. P., Krieger, J. E., Kuramae, E. E., Laigret, F., Lambais, M. R., Leite, L. C., Lemos, E. G. Lemos, M. V., Lopes, S. A., Lopes, C. R., Machado, J. A., Machado, M. A., Madeira, A. M., Madeira, H. M., Marino, C. L., Marques, M. V., Martins, E. A., Martins, E. M., Matsukuma, A. Y., Menck, C. F., Miracca, E. C., Miyaki, C. Y., Monteriro-Vitorello, C. B., Moon, D. H., Nagai, M. A., Nascimento, A. L., Netto, L. E., Nhani, A., Jr., Nobrega, F. G., Nunes, L. R., Oliveira, M. A., de Oliveira, M. C., de Oliveira, R. C., Palmieri, D. A., Paris, A., Peixoto, B. R., Pereira, G. A., Pereira, H. A., Jr., Pesquero, J. B., Quaggio, R. B., Roberto, P. G., Rodrigues, V., de, M. R. A. J., de Rosa, V. E., Jr., de Sa, R. G., Santelli, R. V., Sawasaki, H. E., da Silva, A. C., da Silva, A. M., da Silva, F. R., da Silva, W. A., Jr., da Silveira, J. F., Silvestri, M. L., Siqueira, W. J., de Souza, A. A., de Souza, A. P., Terenzi, M. F., Truffi, D., Tsai, S. M., Tsuhako, M. H., Vallada, H., Van Sluys, M. A., Verjovski-Almeida, S., Vettore, A. L., Zago, M. A., Zatz, M., Meidanis, J., and Setubal, J. C. 2000. The genome sequence of the plant pathogen Xylella fastidiosa. Nature 406:151-159.

60. Singh, R., Ferrin, D. M., and Huang, Q. 2010. First report of Xylella fastidiosa associated with oleander leaf scorch in Louisiana. Plant Dis. 94:274.

61. Stamatakis, A. 2006. RAxML-VI-HPC: maximum likelihood-based phylogenetic analyses with thousands of taxa and mixed models. Bioinformatics 22:2688-2690.

62. Stamatakis, A., Hoover, P., and Rougemont, J. 2008. A rapid bootstrap algorithm for the RAxML Web servers. Syst. Biol. 57:758-771.

63. Su, C. C., Chang, C. J., Yang, W. J., Hsu, S. T., Tzeng, K. C., Jan, F. J., and Deng, W. L. 2011. Specific characters of 16S rRNA gene and 16S-23S rRNA internal transcribed spacer sequences of Xylella fastidiosa pear leaf scorch strains. Online publication. doi:10.1007/s10658-011-9863-6

64. Tamura, K., Peterson, D., Peterson, N., Stecher, G., Nei, M., and Kumar, S MEGA5: molecular evolutionary genetics analysis using maximum likelihood, evolutionary distance, and maximum parsimony methods. Mol. Biol. Evol. In press.

65. Van Sluys, M. A., de Oliveira, M. C., Monteiro-Vitorello, C. B., Miyaki, C. Y., Furlan, L. R., Camargo, L. E., da Silva, A. C., Moon, D. H., Takita, M. A., Lemos, E. G., Machado, M. A., Ferro, M. I., da Silva, F. R., Goldman, M. H., Goldman, G. H., Lemos, M. V., El-Dorry, H., Tsai, S. M., Carrer, H., Carraro, D. M., de Oliveira, R. C., Nunes, L. R., Siqueira, W. J., Coutinho, L. L., Kimura, E. T., Ferro, E. S., Harakava, R., Kuramae, E. E., Marino, C. L., Giglioti, E., Abreu, I. L., Alves, L. M., do Amaral, A. M., Baia, G. S., Blanco, S. R., Brito, M. S., Cannavan, F. S., Celestino, A. V., da Cunha, A. F., Fenille, R. C., Ferro, J. A., Formighieri, E. F., Kishi, L. T., Leoni, S. G., Oliveira, A. R., Rosa, V. E., Jr., Sassaki, F. T., Sena, J. A., de Souza, A. A., Truffi, D., Tsukumo, F., Yanai, G. M., Zaros, L. G., Civerolo, E. L., Simpson, A. J., Almeida, N. F., Jr., Setubal, J. C., and Kitajima, J. P. 2003. Comparative analyses of the complete genome sequences of Pierce's disease and citrus variegated chlorosis strains of Xylella fastidiosa. J. Bacteriol. 185:1018-1026.

66. Versalovic, J., Koeuth, T., and Lupski, J. R. 1991. Distribution of repetitive DNA sequences in eubacteria and application to fingerprinting of bacterial genomes. Nucleic Acids Res. 19:6823-6831.

67. Wells, J. M., Raju, B. C., Hung, H. Y., Weisburg, W. G., Mandelcopaul, L., and Brenner, D. J. 1987. Xylella fastidiosa gen. nov., sp. nov.: gram-negative, xylem-limited, fastidious plant bacteria related to Xanthomonas spp. Int. J. Syst. Bacteriol. 37:136-143. 